International Journal of Heritage, Tourism and Hospitality Vol. (12), No. (2/2), September, 2018 By: Faculty of Tourism and Hotels, Fayoum University, Egypt

\title{
Evaluating the Hospitality Services and Marketing Activities Offered to Medical Tourists in the Egyptian JCI Certified Hospitals \\ Nahla Mohamed Helmy ${ }^{1} \quad$ Michael Magdi Zaki ${ }^{2}$ \\ ${ }^{1}$ High Institute of Tourism, Hotels and Restoration, Abu Quir, Alexandria \\ ${ }^{2}$ Faculty of Tourism and Hotels, South Valley University
}

\section{Abstract}

Travelling abroad for health benefits is not a recent concept, but it has been gaining more momentum and media interest in the last decades. In Egypt, medical tourism has also become one of the arising tourism types that recently emerged. Medical tourism success greatly depends on the quality of hospitality services and marketing activities implemented by hospitals management and offered to medical tourists. The aim of this paper is to evaluate the overall hospitality services and marketing activities in the top-notch medical centers in Egypt, which are the JCI certified hospitals. This evaluation involves both strong points and weak points of hospitality services and marketing activities offered to medical tourists. Strong points are utilized as a model of professional hospitality services and marketing activities, so as to be given to other Egyptian hospitals that plan to receive medical tourists. On the other hand, weak points are employed as lessons to be learned by such Egyptian hospitals through avoiding the JCI hospitals' defects and mistakes. This research has selected seven JCI certified hospitals, representing $77.7 \%$ of the total JCI hospitals in Egypt. Research has tackled a questionnaire with 47 medical tourists in all visited hospitals for getting the quantitative data and an interview with 7 managers working in the seven visited hospitals for obtaining the qualitative data. Field survey analysis confirmed that there are many strong points which embodied in the proficient marketing activities done for attracting a larger number of medical tourists in the JCI hospitals. Moreover, all hospitality standards are generally followed starting from medical tourist arrival till departure. On the other hand, there are some few weak points such as the limited accommodation arrangements for medical tourists' companions, no entertainment activities offered to patients in the visited hospitals as well as the preparation of tourist's sightseeing during the medical tourist visit does not exist.

Keywords: Hospitality services, Marketing activities, Medical Tourists, JCI certified hospitals

\section{Introduction}

There are newly emerged types of tourism such as religious tourism, sport tourism, war tourism, leisure tourism, and medical tourism (Kazemi, 2006). Medical tourism is regarded as one of the most significant kind of tourism in the past 20 years (Connell, 2013). Although medical tourism appeared many years ago, it is still a new trend, with very fast growing not only in developed countries but in developing countries as well (Larisa and Tigu, 2017). Medical tourism is rapidly spreading through worldwide boundaries for reaching health care that includes basically both medical procedures together with travel and tourism (Vitthal et al., 2015). To attain a successful medical tourism within nations, there must be well examined and organized agenda for medical tourism in each country as stated by Delgoshaee et al. (2012).

It is stated that medical tourism immensely rose up by the end of the 1990s through thousands of sick people travelling to some other countries like India, Thailand and Mexico, to obtain their health care, which is actually very expensive and not sufficient in their home countries (Reisman, 2010). On the contrary, medical tourism has recently risen through travelling of rich patients from low-income countries to highstandard medical centers in the United States (Ornstein and Glionna, 2008). 
Ile (2016) and Larisa and Tigu (2017) revealed that medical tourism has been wellorganized, with more focus on quality and safety of health care services, this is besides hospital management with more sophisticated facilities and supplies offered in hospitals. Furthermore, medical tourism is regarded as socio, cultural and economic phenomenon that is related to sustainability of the environment. This phenomenon is exemplified in some countries like Jordan, Singapore, Israel and India that approved medical tourism as one of the main driving factors to economic development of their communities (Rory et al, 2010). The sustainable development of medical tourism is also vitally manifested though obtaining the three columns of highly developed countries which are the environment, the economy and the local community (Valorie et al, 2011).

Kumar and Hussian (2016) proposed that the main reasons behind any successful medical tourism in Malaysia are geography and location of the medical tourism destination, varieties and quality of the offered medical services, the moderate prices of the sold medical services, and finally, the existence of specialized associations as well as professional hospital management. Moreover, they recommended that to get more efficient medical tourism, there must be a notable care from the government and authorized associations in Malaysia.

Research problems are summarized in two important points: (1) the fact that there are no standardized guidelines of hospitality services that offered to medical tourists in the Egyptian hospitals. Accordingly, there are no skills development programs adopted by neither the Ministry of Tourism nor any other authorized tourist associations. (2) Weakness in marketing activities that should be done for attracting a larger number of medical tourists to the Egyptian hospitals. Therefore, this research selected the JCI hospitals as a certified association that should possess standard of operation in many sides including the hospitality services as well as a professional marketing plan.

\section{Literature Review}

Medical Tourism Concept

Connell (2006) stated that concept of medical tourism that has been recently emerged is the travelling of patients abroad within a long distance trip to attain health care such as medical, dental and surgical along with a tour to famous tourist sites in the country. Glinos et al. (2012) confirmed that the notion of a medical tourist is the one who transferred from his own country to another foreign country for obtaining medical treatment and joining visits of the most famous tourist attractions. Sadremomtaz and Agharahimi (2010) added that medical tourism is considered a sort of travel to other countries for some curative purposes such as dentistry, and operation services. This travel, at least, should contain one-night accommodation outside one's destination. As reported by Edelheit et al. (2008), 'medical tourism' is a terminology that means the travelling to other countries not only for curative reasons but also for medical checkups. Navid et al. (2010) clarified that medical tourism is regarded as an economic action which includes professional services skills and also illustrates the splitting of two major sectors which are medicine and tourism. Jagyasi (2008) and Heung et al. (2010) reported that the concept of the term 'Medical Tourism' is a group of activities that the person does for travelling abroad to obtain different medical services together with wellness, health care services, leisure, fun, relaxation, business or other reasons. Medical country destinations and hospitals are known through friends, family, relatives, colleagues, books, media, medical advice, medical insurance companies and 
internet advertising (Alsharif et al.,2010; Anon, 2010; Al-Hinai et al., 2011; Veerasoontorn et al., 2011; Yu and Ko, 2012).

\section{Medical Hotel as a new trend}

Rutes et al. (2001) as well as Hollis and Verma (2012) stated that there are three segments of medical hotels that has been recently appeared with the flourishing of medical tourism. The first is the one that is typically located near the medical centers. The second is the one that mostly owned by hospitals or medical organizations and encompasses all the facilities and services which support the health care. The third is also owned by hospitals but combined with medical facility to offer on-site cure and medical treatment to the guest (patient). Medical hotels guarantee the most appropriate, relaxed and calm accommodation of the guest rather than those hotels with high occupancy of normal guests. Certainly, this type of hotel is lucrative for the owner as it avoids the problems of seasonality with guaranteed guest reservation and occupancy through the regular demand that come from hospitals.

\section{Health tourism Versus Medical Tourism}

Health tourism, according to Bennett et al. (2004), is a kind of entertainment tourism that involves stress relief, joy and relaxation. However, Henderson (2004) mentioned that health tourism is a wide-range category that includes various models of treatments and services. Accordingly, medical tourism has become a subcategory of health tourism. Moreover, Connell (2006) as well as Smith and Puczko (2009) assumed that 'health tourism' consists of 'wellness tourism' and 'medical tourism' the fact that 'medical tourism' is the accurate term that has been utilized in and focusing on medical, surgical or dental mediations, whereas any other different types of health tourism is named 'wellness tourism'. On the other hand, Padma (2006) and Dunn (2007) confirmed that health and medical tourism are different in the complexity and sickness of the disease along with the hazards and side effects that may be resulted from any surgical interference.

\section{Classification of medical tourists}

Based on many different studies in Thailand, Cohen (2008) proposed that there are four categories of medical tourists which are: 1) 'medicated tourists' who are receiving medication for the accidents or any health problems that occur during the tourist visit. 2) 'medical tourist proper' this type of tourist is the one that visit the country especially for receiving specific medical treatment, or who may decide suddenly to receive some medical treatment during the tour visit. 3) "Vacationing patients' they are tourists that mainly visit the country for medical purposes but supported with some visits to tourist sites, especially during the convalescence time. 4) 'Mere patients' are those that visit the country for the medical reasons only and have nothing to do with holiday opportunities. Most probably the 'mere patients' visit is very short like dentistry or vision/sight correction operations.

Bookman and Bookman (2007) as well as Kangas (2010) and Ramirez de Arellano (2011) reported that there are five sorts of medical tourists: First, the 'elite patients' that travel from different expensive medical tourism destinations for receiving professional treatment. Second, 'second tier of wealthy patients' that recorded the highest number of medical tourists. They are the middle income medical tourists that move for lower prices but necessary medical services while their medical insurance is inadequate in their country. Third, 'diasporic patients' of different socio-economic status from approximately rich medical tourists like Maltese and Koreans to less 
wealthy patients like Mexicans. Fourth, 'cross-border' patients. They include many diasporic patients through organized groups in Europe that look for cheaper and fast treatment in neighboring countries. Fifth and last, 'reluctant and desperate' medical tourists from Burma or Yemen that come from developed nations and have no considerable health care at their home countries and travel with very cheap prices for curative reasons and always prefer the cost-effective local treatment.

\section{Main factors affecting medical tourism}

According to Kazemi (2008), the most significant factors affecting medical tourism are well organized hospital management, qualified functions of health centers, varieties of medical services and treatments, cost effectiveness of medical services, natural beauty of location and nice climate of the destination as well as advertising and promotional activities about the medical services offered, and last but not the least, the security of the visited destination. Moreover, Beerli and Martín (2004) and Smith et al. (2011) confirmed that country image and profile is a key factor affecting medical tourism at any country along with the political environment or political stability with no corruption and good rule of law. Furthermore, there are specific factors related to the similarities or discrepancies between the home country of the medical tourist and host country.

Gill and Singh (2011) argued that one of the leading factors for American patients is quality of facilities and services. Therefore, the standards of hospitals (ISO) and international characteristics of the international accreditations must be taken into account. Heung et al. (2011) added that the comprehensive quality of health care, reputation and physicians are highly significant and leading factors.

\section{Medical Tourism in Egypt}

Abu-ElEnain and Yahia (2016) stated that although medical tourism is profitable especially at the time of decline, it may confront many problems in practical performance. However, medical tourism can also offer motivations to the tourism workers who have almost left their jobs and may shift to other careers. Profits are not only restricted to this, but also extended to include development of existing tourism types and introducing new ones as well as increasing the tourist numbers and their expenditure percentage. In their study they conveyed that the difficulties facing medical tourism in Egypt are: 1) Unavailability of adequate information about health tourism as a result of deficient activities of tourism sector, 2) Many of hospitals urgently need changes to improve the effectiveness and proficiency of their operations. The major challenges confronting these organizations will be the difficulty of being awarded the international accreditation, upgrade their nursing systems and certify their doctors, and 3) many of hospitals will need to attain the hospitality and marketing know-how needed to improve their competitive products and identify target markets. Ayoub (2017) pointed out that one positive and important aspect of the medical tourism model is the opportunity of Egypt to expand and develop its health infrastructure and health human resource base so that Egyptian government and organizations have to start designing its own vision and strategic objectives for medical tourism sector.

Helmy (2011) concluded that the Egyptian medical tourism development equation, however, implies the necessity of considering three service pillars of the "service value chain" in order to develop a competent medical tourism destination. Although the development of a progressive healthcare sector is a condition for offering compatible medical services, all destinations have to consider the development of the 
other two main elements to be able competing in the international market of medical tourism: the support services as well as the complementary travel and tourism services.

\section{The application of hospitality services in hospitals}

According to Lashley and Morrison (2000), hospitality provides a promise to match guests' needs and requirements as the main emphasis on commercial operations through a host and guest relationship. The host and guest relationship is further categorized by hospitableness typically drawn-out by the host to the guests and then exchanged by the guest to the host. Hospitableness involves a friendly attitude within welcoming environment (Oh and Pizam, 2008).

Equivalents can be drawn between the guest exchange in hotels and hospitals and for some time the two industries have been compared regarding the amenities offered. Equivalents involve the 24-hour housing services including bed services, maintenance, security, and foodservice. Both environments also correspond to mega planned and unplanned changes in guest request. Mixing, collaborating, and managing various types of customers bring many other resemblances (Fottler et al., 2006). Hospitals have used for a long time hotel kind, images and structural design to appeal to and confirm on potential patients (Adams, 2008). Furthermore, Becker et al. (2008) stated that hospitals with more hospitality-focused environment were also found to maintain and keep their staff as well as maximize their satisfactory levels at a higher ratio than those with environments of minimum attractiveness. Goldman and Romley (2008) notified that amenities are exemplified in tasty and healthy food, alert staff, and enjoyable surroundings, all elementary requests in hospitality industry, were found to play key role in creating hospital demand, and patients value hotel like elements such as individual and personal friendly rooms, views, room service meals, and massage service twice as much as they value the medical name and image when making hospital selections.

Many hospitals have hired a people - processes - place framework, which is always used by the hospitality industry to increase service quality. For instance, some hospitals have subcontracted their dining services, maintenance, facilities management, engineering, biomedical equipment management, and housekeeping functions to hospitality services providers such as ARAMARK Healthcare and Sodexo, while others have contracted with hotel operating associations or hospitality related companies such as the Ritz-Carlton hotel company, Four seasons hotels and resorts, and the Walt Disney company for training in service operation, running and administration (Wu et al., 2013).

\section{Hospital Food Services}

A hospital's Food Service includes the sector that provides meals to hospital workforce, patients and their families by joining a dietary regime and supporting nutrition education. Because food in hospitals is a supplementary element to medical treatment, it should be made in acceptable standardized hygienic and sanitary situation, due to the fact that food cross-contaminated diseases affect hospitalized and immunosuppressed patients with greater danger (Edwards and Hartwell, 2006). Therefore, the implementation of firm practices in sanitary safety during the production of hospital meals is obligatory and then more organic harm may be evaded (Mentziou et al., 2014).

Hospital menus should be based on medical needs, as well as on patients' favorites. Other important characteristics such as variety, quality, and taste of food should be involved. Furthermore, the hospital environment and a friendly helpful attitude of the 
nursing staff are highly important elements that should be considered in a new competitive approach to a complex problem as mentioned by Naithani et al. (2009). The standard of hospitality services offered to medical tourists

Wu et al., (2013) and Laurren (2013) argued that hospitality elements, applied in the current hospitals, cover the following: hotel-like rooms and decor; real hotels combined into medical centers; hotel-quality food, room service, and eating facilities for families; welcoming lobbies and public spaces; customer-focused service training; boosted service offerings, including concierges (information desk services); spas or therapy centers; hotel-style structure and easily-found tools; and entertainment landscapes. Chosen elements that have prospective for future collaboration involves executive salons and/or commonly shared lobbies with free wireless Internet (Wi-Fi access) and refreshments, centralized controls for patients, and easily movable furniture.

As declared by Guzman (2014), other hospitality features (Services) in hospitals can be categorized into four groups:

1) Food service (24/7 rooms service - cafeterias - restaurants)

2) Rooms (room management technologies - safe box- hospital services guide rooms touch screen - international calls - internet - VIP suites)

3) Customer service (concierge service - executive lounges - bellhop - valet parking - check out express)

4) Entertainment and Additional Services (spa - classes - gym - informative touch screens - game centers, libraries and art galleries)

The Joint Commission International organization and JCI Certification

According to the report of Joint Commission International (2017), the joint Commission International is the organization that grants the JCI certification to the hospitals. Founded in 1951. The Joint Commission accredits and certifies more than 21,000 health care organizations and programs in the United States. An independent, non-profit organization, The Joint Commission is the nation's oldest and largest standards-setting and accrediting body in health care. JCI standards and evaluation methods stand alone in the world as unique tools designed to drive positive change. Its standards and evaluation methods are:

- Designed to stimulate and support sustained quality improvement

- Created to reduce risk

- Focused on building a culture of patient safety

- Developed by health care experts from around the world - and tested in every world region

- Developed by health professionals specifically for the health care sector

- Applicable to individual health care organizations and national health care systems

\section{Research Methodology}

Research objective

Providing a professional model of hospitality services and marketing activities to be submitted to the Egyptian hospitals that are planning to receive and serve medical tourists in their establishments. This model depends on two key important features resulted from an overall evaluation of hospitality services and marketing activities offered to medical tourists in the visited JCI certified hospitals: Strong points and weak points. For further clarification, see figure (1) 
International Journal of Heritage, Tourism and Hospitality Vol. (12), No. (2/2), September, 2018 By: Faculty of Tourism and Hotels, Fayoum University, Egypt

Figure 1: Mechanism of making up a model of professional hospitality services and marketing activities

An overall evaluation of hospitality services and marketing activities offered to medical tourists in the $\mathrm{JCl}$ hospitals

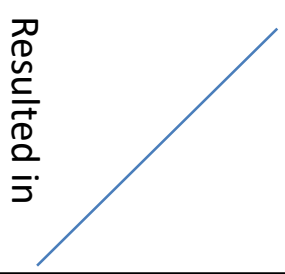

Strong Points

List of Standardized hospitality

services and marketing activities

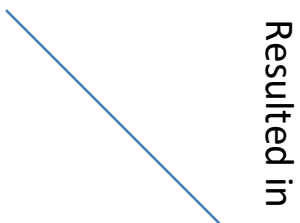

Weak Points

List of Mistakes and lessons for learning and improvement

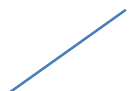

A model of professional hospitality services and marketing activities offered to medical tourists

\section{Population and sample selection}

The research has selected JCI certified hospitals since they represent the top-notch hospitals with standardized services in Egypt which are internationally recognized and accredited. Accordingly, they offer the best services and represent a good image of typically proficient hospitality services offered to medical tourists, which are needed for setting the model of professional standardized hospitality services and marketing activities.

As stated by the Joint Commission International (2017), there are 10 medical organizations in Egypt given the JCI certification. They are JCI certified hospitals, medical centers and laboratories. Table (1) clarifies the list of these medical organizations.

Table 1: List JCI certified hospitals, medical centerss and laboratories in Egypt

\begin{tabular}{|c|l|c|}
\hline Serial & Name of Medical Organization & Date of JCI Certification \\
\hline 1 & As Salam International Hospital & 11 Sept., 2015 \\
\hline 2 & Allied Labs & 22 Dec., 2015 \\
\hline 3 & Children Cancer Hospital Egypt (CCHE) 57357 & 15 Jan., 2016 \\
\hline 4 & Dar Al Fouad Hospital & 07 July, 2005 \\
\hline 5 & El Araby Hospital & 26 May, 2017 \\
\hline 6 & International Eye Hospital & 13 Nov., 2015 \\
\hline 7 & International Medical Center & 03 June, 2016 \\
\hline 8 & Saudi German Hospital Cairo & 19 Jan., 2018 \\
\hline 9 & Wadi El Nil Hospital & 29 March, 2013 \\
\hline 10 & Maghraby Eye Hospital & 17 Aug., 2009 \\
\hline
\end{tabular}

Source: Joint Commission International - JCI, (2017)

To execute the overall evaluation, the research has chosen 7 hospitals, representing $77.7 \%$ of the total JCI certified hospitals in Egypt, since the total number of JCI certified hospitals in Egypt is 9. These hospitals are stated as follows:

- As Salam International Hospital in Maadi, Cairo

- Dar El Fouad Hospital in $6^{\text {th }}$ October City, Giza 
- Saudi German Hospital in Heliopolis, Cairo

- International Eye Hospital in Dokki, Giza

- Wadi El Nil Hospital in Kobri El Kobba, Cairo

- El Maghrabi in Saieda Eisha, Cairo

- $\quad$ El Araby Hospital in Sadat City, Menoufia

Sampling considers the variety in geographical areas which embodied in 3 different Egyptian Governorates: Cairo, Giza and Menoufia. It was too difficult to meet 47 medical tourists at once and to distribute the questionnaire among them. This is due to the fact that all of them have not been available during the time of visiting the hospital. For example, Arabs mostly visit Egypt in summer. Accordingly, we visited the hospitals and met medical tourists from time to time during special seasonal periods not all over the year.

\section{Data Collection}

The research has developed a questionnaire distributed among 47 medical tourists in the visited hospitals. The questionnaires result in quantitative data related to the hospitality services offered to medical tourists within the visited hospitals regarding the following topics:

- Demographic data about medical tourists who visit the selected JCI hospitals

- Preference and choices of medical tourists

- Evaluation of hospitality services in the eyes of the medical tourists

- Overall evaluation about the comprehensive medical visit to Egypt according to respondents' point of views in terms of totally disagree, disagree, relatively agree, agree and strongly agree.

An in-depth interview has been also been developed with 7 managers working in the visited JCI certified hospitals whose jobs are related to marketing, public relations and international medical relation. The interview contains key questions addressing the hospitality services and marketing activities offered to medical tourists so as to collect qualitative data that support in the targeted overall evaluation in terms of the following:

- Nationalities of the medical tourists

- Frequent diseases and treatments mostly required by medical tourists

- Marketing activities with selling techniques handled by hospital management

- Problems and difficulties confronting medical tourists

- Training and skills development activities done by hospital management

- Unique and distinguishes features occurring in visited hospitals that attract a larger number of medical tourists

Research data has been collected during the field survey visit to the selected 7 JCI hospitals. It lasted for approximately 6 months from January till June, 2018. Each hospital has been visited from $2-3$ times to follow up the collection and gathering of the medical tourists' responses on the questionnaire, along with the interview with the concerned managers.

\section{Research Findings}

First: Questionnaire Analysis

The questionnaires have been distributed among 70 medical tourists, 10 patients per hospital. It has been noticed that 23 questionnaires are invalid and 47 ones are valid, that represent $67.14 \%$. After sorting out the invalid questionnaires, data were coded, computed, and analyzed. The obtained results of patients' questionnaire were discussed using two methods of analysis:

1) Descriptive analysis: In which the results are discussed along with percentages of the various frequencies obtained from each question. 
2) Coefficient analysis: In which analytical relations among some of the chosen data were investigated by descriptive statistics. Statistical Package for Social Science (SPSS) computer program (version 24 windows) was manipulated for data analysis. The statistical analysis methods included: Cronbach's Alp ha reliability, ShapiroWilk, Mean, Standard Deviation, Pearson Correlation, Multiple Linear Regressions, and Kruskal-Wallis test.

Questionnaire Reliability Measurement

Table 2: Cronbach's Alpha reliability coefficient and Shapiro-Wilk normality test

\begin{tabular}{|c|c|c|c|c|}
\hline Elements of Hospitality Services & No. & $\begin{array}{l}\text { Reliability } \\
\text { Coefficient }\end{array}$ & $\begin{array}{l}\text { Reliability } \\
\text { Ratio }\end{array}$ & $\begin{array}{l}\text { Shapiro-Wilk } \\
\text { (sig.) }\end{array}$ \\
\hline - Hospital reservation and registration procedures & 3 & 0.991 & $99 \%$ & 0.026 \\
\hline - $\quad$ Hospital internet services & 2 & 0.992 & $99 \%$ & 0.000 \\
\hline - $\quad$ Travel and transportation services & 3 & 0.991 & $99 \%$ & 0.005 \\
\hline - Hospital welcoming and accommodation services & 7 & 0.991 & $99 \%$ & 0.005 \\
\hline - Quality of patient room & 9 & 0.991 & $99 \%$ & 0.000 \\
\hline - Grooming and performance of housekeeping staff & 6 & 0.991 & $99 \%$ & 0.002 \\
\hline - $\quad$ Medical services follow up and facilities & 4 & 0.991 & $99 \%$ & 0.001 \\
\hline - $\quad$ Food quality and menu & 8 & 0.991 & $99 \%$ & 0.025 \\
\hline - Food service and cafeteria facility & 5 & 0.991 & $99 \%$ & 0.002 \\
\hline - $\quad$ Performance of food service staff & 8 & 0.991 & $99 \%$ & 0.008 \\
\hline - Hospital spa, wellness and therapy programs & 3 & 0.995 & $99 \%$ & 0.000 \\
\hline $\begin{array}{l}\text { - Hospital entertainment and patient country tour/visit } \\
\text { programs }\end{array}$ & 3 & 0.0 & 0.0 & 0.000 \\
\hline - Dry clean and laundry facilities and services & 2 & 0.992 & $99 \%$ & 0.000 \\
\hline - Companions' (non-patient guests) accommodation & 5 & 0.991 & $99 \%$ & 0.001 \\
\hline - Overall evaluation & 4 & 0.991 & $99 \%$ & 0.020 \\
\hline All questionnaire & 72 & 0.992 & $99 \%$ & 0.006 \\
\hline
\end{tabular}

The reliability of the scales was tested by calculating their coefficient alpha (Cronbach's alpha) to define and mark the degree of internal consistency between the measurements used in the study. Cronbach's alpha should meet the recommended significance of 0.70 or higher.

The value of Cronbach's Alpha reliability coefficient was high for all the questionnaire elements, except hospital entertainment and patient country tour/visit programs, which the reliability Ratio was $99 \%$. While the average value of Cronbach's Alpha for all the questionnaire elements (0.992), which is acceptable value and this, means that the coefficient of reliability of the questionnaire indicates the compatibility of the paragraphs of the questionnaire.

Conducting a Shapiro-Wilk Normality Test:

The Shapiro-Wilk normality test for all the questionnaire elements, show (sig. $=<0.05$ ), indicating that the distribution is abnormal.

Table 3: Questions Answered Scale

\begin{tabular}{|c|c|c|c|c|c|}
\hline Code & 1 & 2 & 3 & 4 & 5 \\
\hline Range & $1 \geq 1.8$ & $1.8 \geq 2.6$ & $2.6 \geq 3.4$ & $3.4 \geq 4.2$ & $4.2 \geq 5$ \\
\hline Category & $\begin{array}{c}\text { Totally } \\
\text { disagree }\end{array}$ & Disagree & Relatively agree & Agree & Strongly Agree \\
\hline
\end{tabular}

\section{The Conceptual Framework}

The study conceptual framework consists of the independent variables which are the hospitality services and facilities elements and their relationship and their effect on the dependent variable, which is patients' satisfaction under the controlled variables, which are demographic data. 
International Journal of Heritage, Tourism and Hospitality Vol. (12), No. (2/2), September, 2018

By: Faculty of Tourism and Hotels, Fayoum University, Egypt

Figure 2: Diagram of study model

- Hospital reservation and registration procedures

- Hospital internet services

- Travel and transportation services

- Hospital welcoming and accommodation services

- Quality of patient room

- Grooming and performance of housekeeping staff

- Medical services follow up and facilities

- Food quality and menu

- Food service and cafeteria facility

- Performance of food service staff

- Hospital spa, wellness and therapy programs

- Hospital entertainment and patient country

tour/visit programs

Independent Variables

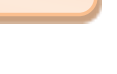

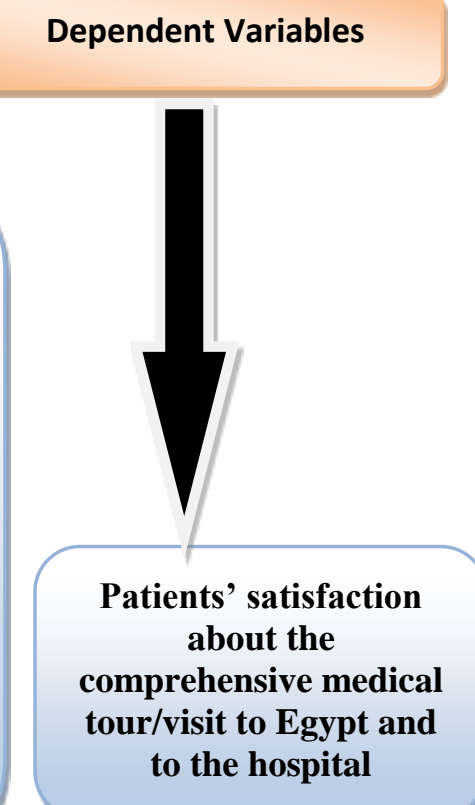

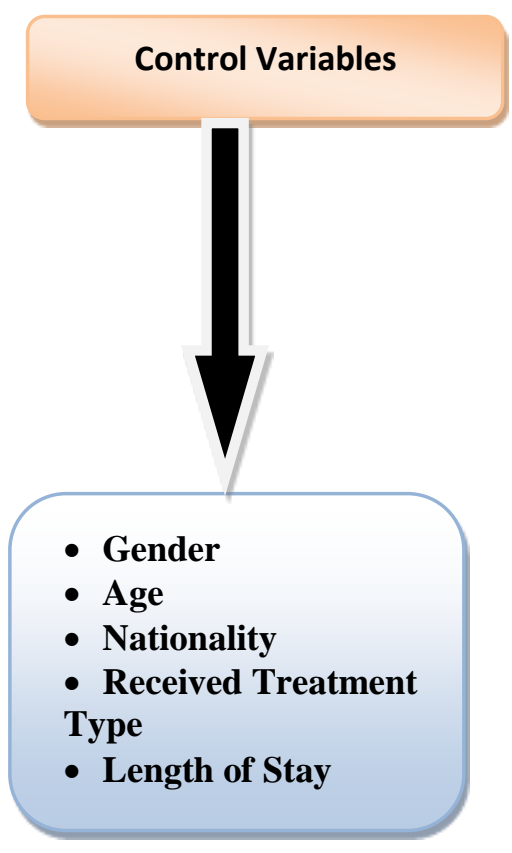

Analysis of the questionnaire results according to patient' views and responses offer the following findings:

Part one: Demographic and personal data analysis

This section was concerned with recognizing the personal information of the patients including gender, age, and nationality, type of received treatment as well as length of stay.

Table 4: patients' demographic and personal data analysis

\begin{tabular}{|c|c|c|c|c|c|}
\hline \multicolumn{2}{|c|}{ Demographic data } & Freq. & $\%$ & Mean & $\begin{array}{l}\text { Std. } \\
\text { Dev. }\end{array}$ \\
\hline \multirow{2}{*}{ Gender } & - $\quad$ Male & 39 & $82.98 \%$ & \multirow{2}{*}{1.17} & \multirow{2}{*}{0.38} \\
\hline & - $\quad$ Female & 8 & $17.02 \%$ & & \\
\hline \multirow{3}{*}{ Age } & - $\quad$ Less than 35 years & 3 & $6.38 \%$ & \multirow{3}{*}{2.17} & \multirow{3}{*}{0.52} \\
\hline & - $35-50$ years & 33 & $70.21 \%$ & & \\
\hline & - More than 50 years & 11 & $23.40 \%$ & & \\
\hline \multirow{8}{*}{ Nationality } & - $\quad$ Saudi Arabian & 13 & $27.66 \%$ & \multirow{8}{*}{3.26} & \multirow{8}{*}{2.48} \\
\hline & - $\quad$ Kuwaiti & 14 & $29.79 \%$ & & \\
\hline & - $\quad$ Sudanese & 5 & $10.64 \%$ & & \\
\hline & - $\quad$ Yemeni & 3 & $6.38 \%$ & & \\
\hline & - $\quad$ Syrian & 2 & $4.26 \%$ & & \\
\hline & - Libyan & 2 & $4.26 \%$ & & \\
\hline & - Jordanian & 1 & $2.13 \%$ & & \\
\hline & - $\quad$ Others & 7 & $14.89 \%$ & & \\
\hline \multirow{7}{*}{$\begin{array}{c}\text { Received } \\
\text { Treatment Type }\end{array}$} & - General Surgery & 7 & $14.89 \%$ & \multirow{7}{*}{3.74} & \multirow{7}{*}{1.66} \\
\hline & - $\quad$ Plastic surgery & 3 & $6.38 \%$ & & \\
\hline & - $\quad$ Kidney Transplantation & 11 & $23.40 \%$ & & \\
\hline & - $\quad$ Cardiology & 9 & $19.15 \%$ & & \\
\hline & - Ophthalmology & 8 & $17.03 \%$ & & \\
\hline & - Neurology & 9 & $19.15 \%$ & & \\
\hline & - Others & 0 & $0.00 \%$ & & \\
\hline \multirow{3}{*}{ Length of Stay } & - Less than 2 week & 9 & $19.15 \%$ & \multirow{3}{*}{2.02} & \multirow{3}{*}{0.64} \\
\hline & - From 2 to 4 week & 28 & $59.57 \%$ & & \\
\hline & - More than 4 week & 10 & $21.28 \%$ & & \\
\hline
\end{tabular}


Table (4) clearly reflects the demographic profile of the patients' respondents. The results of descriptive analysis for demographic information indicated that among the analyzed samples $(\mathrm{n}=47),(82.98 \%)$ of the respondents were male, with $(17.02 \%)$ being male. While Std. Deviation 0.38 , suggesting homogeneity answers to the mean values which stood at 1.17 .

In terms of patients' age group, the ages of the respondents ranged from 35 to above 50 years. It is clear that $(70.21 \%)$ of all the patients were at the age between 35 to 50 years; followed by the patients whose age of more than 50 years with a percentage of $(23.40 \%)$. On the other hand, $(6.38 \%)$ of them were at the age of under 35 years. While Std. Deviation 0.52, suggesting homogeneity answers to the mean values which stood at 2.17 .

With regard to nationalities of patients (respondents' country of origin), The highest percent $(57.45 \%)$ of these countries belonged to Kuwait and Saudi Arabia (29.79\% were Kuwaiti and $27.66 \%$ were Saudi), $14.89 \%$ of all patients were Nigerian, Kenyan and Iraqi, $10.64 \%$ of them were Sudanese, $8.52 \%$ of them were Syrian and Libyan (4.26\% each), $6.38 \%$ of them were Yemeni, while $2.13 \%$ of them were Jordanian. This illustrated that most of the patients were from Arab and African countries, where most of them share the same religion and culture with Egypt. While Std. Deviation 2.48, suggesting dispersion answers to the mean values which stood at 3.26.

In terms of the types of medical services accessed by the respondents (type of received treatment). Kidney transplantation was the highest medical services accessed (23.40\%), followed by neurology (19.15\%), cardiology (19.15\%) and ophthalmology $(17.03 \%)$. Though, the remaining medical services had less than $15 \%$ frequency, General Surgery $(14.89 \%)$, while, plastic surgery had only $(6.38 \%)$. while Std. Deviation 1.66, suggesting dispersion answers to the mean values which stood at 3.74. With reference to length of stay, $(59.57 \%)$ of all the patients spent in hospitals from two to four week; while $(21.28 \%)$ of them spent more than four weeks. on the other hand, (19.15\%) of them spend less than two weeks. while Std. Deviation 0.64, suggesting dispersion answers to the mean values which stood at 2.02.

Table 5: Kruskal-Wallis test for statistically significant different between patients' responses related to nationality and length of stay

\begin{tabular}{|c|c|c|c|}
\hline parameters & Chi-square & df & Sig. \\
\hline Nationality & 46.0 & 7 & 0.000 \\
\hline Length of Stay & 46.0 & 2 & 0.000 \\
\hline
\end{tabular}

As shown in Table (5), where that sig. $=0.000<0.01$, there is statistically significant different between patients' responses related to nationality, and there is statistically significant different between patients' responses related to length of stay.

Part two: Preference and Choice

Visiting Egypt for the first time as a medical tourist

Table 6: Patients' answers regarding whether they have visited Egypt as a medical tourist

\begin{tabular}{|c|c|c|c|c|}
\hline Answer & Freq. & $\%$ & Mean & Std. Deviation \\
\hline - Yes & 32 & 68.09 & \multirow{3}{*}{1.32} & \multirow{3}{*}{0.47} \\
\hline - $\mathrm{No}$ & 15 & 31.91 & & \\
\hline Total & 47 & $100 \%$ & & \\
\hline
\end{tabular}

As shown in Table (6), it can be seen that $68.09 \%$ of all the patients visited Egypt as a medical tourist for the first time, meanwhile, $31.91 \%$ of them did not visit Egypt as a medical tourist for the first time. While Std. Deviation 0.47, suggesting homogeneity answers to the mean values which stood at 1.32 . 
International Journal of Heritage, Tourism and Hospitality Vol. (12), No. (2/2), September, 2018 By: Faculty of Tourism and Hotels, Fayoum University, Egypt

\section{Source of patients' awareness of the hospital}

Table 7: Source of patients' awareness of the hospital

\begin{tabular}{|c|c|c|c|c|}
\hline Answer & Freq. & $\%$ & Mean & Std. Deviation \\
\hline - $\quad$ Social Media & 20 & $42.55 \%$ & \multirow{6}{*}{2.85} & \multirow{6}{*}{1.74} \\
\hline - $\quad$ Travel Agent & 0 & $0.00 \%$ & & \\
\hline - $\quad$ Friends/Relatives & 8 & $17.02 \%$ & & \\
\hline - $\quad$ Physician/Doctor & 5 & $10.64 \%$ & & \\
\hline - $\quad$ Others & 14 & $29.79 \%$ & & \\
\hline Total & 47 & $100 \%$ & & \\
\hline
\end{tabular}

As shown in Table (7), 42.55\% of all the patients know the hospital and its services through social media, compared to $29.79 \%$ of them know through other ways such as medical insurance companies. Some of the all patients $(17.02 \%)$ know the hospitals through the friends and relatives. However, only $10.64 \%$ of all patients know the hospital through the recommendations of the Physicians. While Std. Deviation 1.74, suggesting dispersion answers to the mean values which stood at 2.85 .

Reasons for choosing Egypt as a medical site

Table 8: Reasons for choosing Egypt as a medical site

\begin{tabular}{|c|c|c|c|c|}
\hline Answer & Freq. & $\%$ & Mean & Std. Deviation \\
\hline - $\quad$ Good international medical reputation & 14 & $29.79 \%$ & \multirow{6}{*}{2.15} & \multirow{6}{*}{1.14} \\
\hline - $\quad$ Low cost and moderate price & 23 & $48.94 \%$ & & \\
\hline - $\quad$ Attractive tourist site & 1 & $2.13 \%$ & & \\
\hline - $\quad$ Previous successful experience & 7 & $14.89 \%$ & & \\
\hline - $\quad$ Others & 2 & $4.26 \%$ & & \\
\hline Total & 47 & $100 \%$ & & \\
\hline
\end{tabular}

The data presented in Table (8) showed that the highest factor category that influences respondents' choice of Egypt as a medical site was low cost and moderate price (48.94\%), followed by "good international medical reputation" $(29.79 \%)$ and " Previous successful experience" (14.89\%). On the other hand, $4.26 \%$ of all the respondents chose Egypt as a medical site for other reasons such as hospitality services and facilities. Only, 2.13\% of all the respondents preferred Egypt as an attractive tourist site. While Std. Deviation 1.14, suggesting dispersion answers to the mean values which stood at 2.15.

Reasons for choosing particularly this hospital

Table 9: Reasons for choosing particularly this hospital

\begin{tabular}{|ll|c|c|c|c|}
\hline \multicolumn{1}{|c|}{ Answer } & Freq. & $\%$ & Mean & Std. Deviation \\
\hline - & Well-known International Medical entity & 5 & $10.64 \%$ & \multirow{2}{*}{2.26} & \multirow{2}{*}{0.64} \\
\cline { 1 - 3 } - $\quad$ Low Cost and good price & 25 & $53.19 \%$ & & \\
\cline { 1 - 3 } - & $\begin{array}{l}\text { Reputable hospital management, hospitality } \\
\text { services and facilities }\end{array}$ & 17 & $36.17 \%$ & & \\
\cline { 1 - 3 } - $\quad$ Others & 0 & $0.00 \%$ & & \\
\cline { 1 - 3 } Total & 47 & $100 \%$ & & \\
\hline
\end{tabular}

From the findings presented in Table (9), it can be seen that more than half (53.19\%) of all patients chose the hospital as a medical entity for treatment because of the factor of low cost and good price (travel costs, accommodation costs, and medical treatment costs); while, $36.17 \%$ of them chose the hospital for the reputable hospital management and its good services and facilities (high-quality treatments and supplies and experience of doctors). On the other hand, $10.64 \%$ of all patients chose the hospital as well-known international medical entity (internationally certified medical hospitals - JCI certified). While Std. Deviation 0.64, suggesting dispersion answers to the mean values which stood at 2.26. 
International Journal of Heritage, Tourism and Hospitality Vol. (12), No. (2/2), September, 2018 By: Faculty of Tourism and Hotels, Fayoum University, Egypt

Visiting other countries as a medical tourist

Table 10: Visiting other countries as a medical tourist 5) Did you visit other countries as a medical tourist?

\begin{tabular}{|c|c|c|c|c|}
\hline Answer & Freq. & $\%$ & Mean & Std. Deviation \\
\hline - $\quad$ Yes & 8 & $17.02 \%$ & \multirow{3}{*}{1.83} & \multirow{3}{*}{0.38} \\
\hline - $\quad$ No & 39 & $82.98 \%$ & & \\
\hline Total & 47 & $100 \%$ & & \\
\hline \multicolumn{5}{|c|}{ A) If yes, Which countries did you visit? } \\
\hline Answer & Freq. & $\%$ & Mean & Std. Deviation \\
\hline - $\quad$ Arabian countries & 3 & 37.5 & \multirow{7}{*}{2.38} & \multirow{7}{*}{1.19} \\
\hline - $\quad$ African countries & 0 & 0 & & \\
\hline - $\quad$ Asian countries & 4 & 50 & & \\
\hline - $\quad$ European countries & 1 & 12.5 & & \\
\hline • USAID & 0 & 0 & & \\
\hline - $\quad$ Others & 0 & 0 & & \\
\hline Total & 8 & $100 \%$ & & \\
\hline \multicolumn{5}{|c|}{ B) What's your overall evaluation about your medical visit in these countries? } \\
\hline Answer & Freq. & $\%$ & Mean & Std. Deviation \\
\hline - $\quad$ Definitely dissatisfied & 0 & $0 \%$ & \multirow{6}{*}{3.25} & \multirow{6}{*}{1.04} \\
\hline - $\quad$ Dissatisfied & 2 & 25 & & \\
\hline - $\quad$ Somehow satisfied & 3 & 37.5 & & \\
\hline - $\quad$ Satisfied & 2 & 25 & & \\
\hline - $\quad$ Completely satisfied & 1 & 12.5 & & \\
\hline Total & 8 & $100 \%$ & & \\
\hline \multicolumn{5}{|c|}{ C) What are the medical tourism distinguished elements did you experience in these countries? } \\
\hline Answer & Freq. & $\%$ & Mean & Std. Deviation \\
\hline - $\quad$ Costs and expenses & 2 & 25 & \multirow{5}{*}{2.25} & \multirow{5}{*}{0.89} \\
\hline - Destination attractiveness & 2 & 25 & & \\
\hline - $\quad$ Medical facilities and services & 4 & 50 & & \\
\hline - $\quad$ Others & 0 & $0 \%$ & & \\
\hline Total & 8 & $100 \%$ & & \\
\hline
\end{tabular}

The results shown in table (10) clearly depict that $82.98 \%$ of all patients did not visit any other country as a medical tourist. Meanwhile, $17.02 \%$ of them visited another country as a medical tourist. While Std. Deviation 0.38, suggesting homogeneity answers to the mean values which stood at 1.83 .

The highest percent $(50 \%)$ of visiting other countries as a medical tourist belonged to the Asian countries which are India, Malaysia and Singapore, followed by Arabian countries $(37.5 \%)$ which are Jordan and Lebanon, then European countries (12.5\%) which is only Germany. While Std. Deviation 1.19, suggesting dispersion answers to the mean values which stood at 2.38 .

Also, table (10) presented that $37.5 \%$ of all the respondents were somehow satisfied with the medical visit in these countries; while, $25 \%$ of them were satisfied. On the other hand, $25 \%$ of all the respondents were dissatisfied with the medical visit in these countries; while, $12.5 \%$ of them completely satisfied. while Std. Deviation 1.04, suggesting dispersion answers to the mean values which stood at 3.25.

According to the results of the analysis of distinguished elements regarding patients' experience of medical tourism in these countries. The results illustrated that the highest element that influence respondents' experience of medical tourism in other countries was "medical facilities and services" (50\%) such as the popularity of these countries in medical treatment, followed by "costs and expenses" (25\%), and "destination attractiveness" (25\%) such as easy access, popular tourist attractions and the programs and packages of medical tourism in these countries (accommodation treatment - tours). While Std. Deviation 0.89, suggesting dispersion answers to the mean values which stood at 2.25. 
International Journal of Heritage, Tourism and Hospitality Vol. (12), No. (2/2), September, 2018 By: Faculty of Tourism and Hotels, Fayoum University, Egypt

\section{Part three: Hospitality Services Evaluation}

Table11: Hospitality services and facilities in hospitals

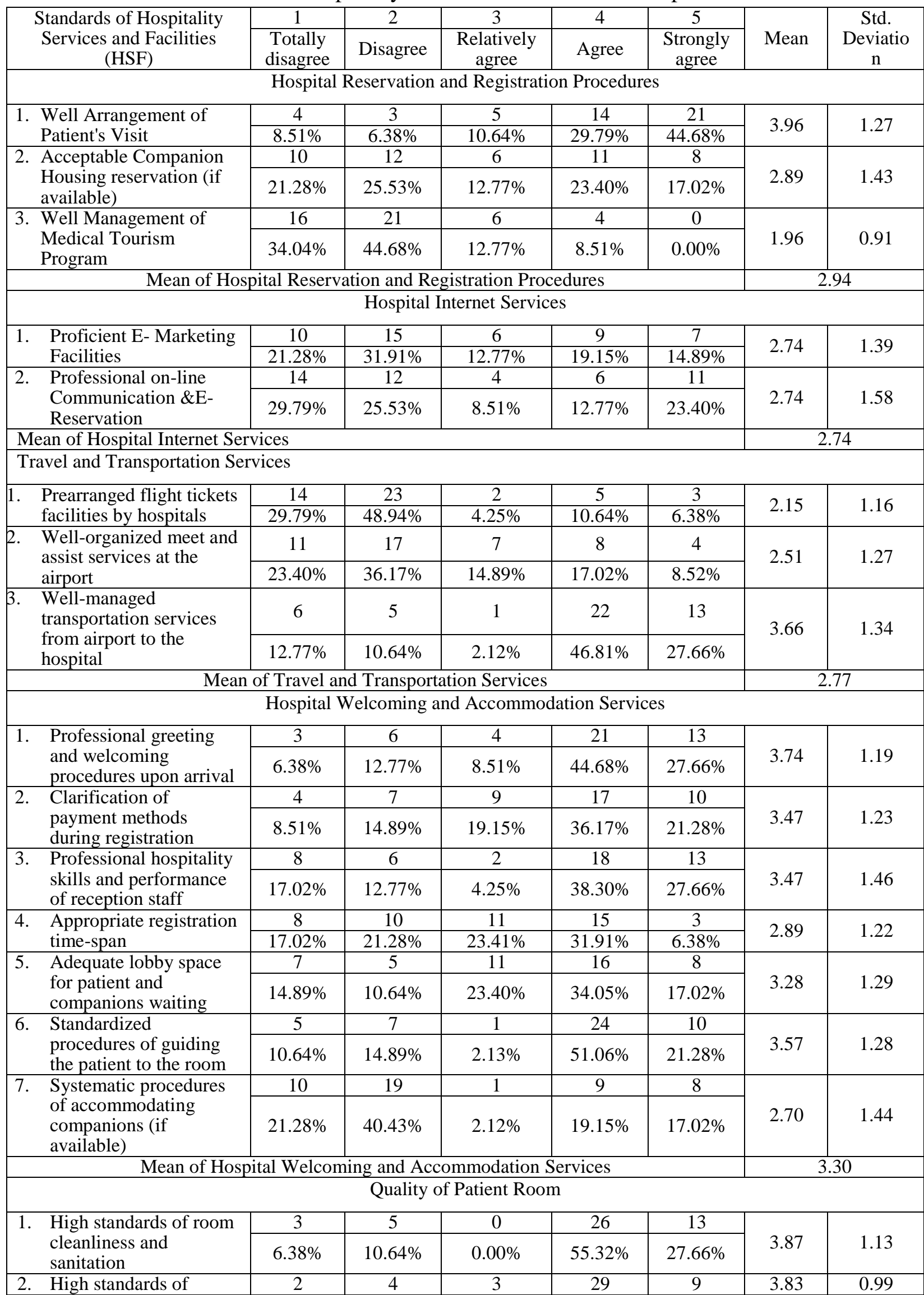


International Journal of Heritage, Tourism and Hospitality Vol. (12), No. (2/2), September, 2018 By: Faculty of Tourism and Hotels, Fayoum University, Egypt

\begin{tabular}{|c|c|c|c|c|c|c|c|c|}
\hline & $\begin{array}{l}\text { toilets sanitization and } \\
\text { sterilization }\end{array}$ & $4.26 \%$ & $8.51 \%$ & $6.38 \%$ & $61.70 \%$ & $19.15 \%$ & & \\
\hline \multirow[t]{2}{*}{3} & \multirow{2}{*}{$\begin{array}{l}\text { Available room and } \\
\text { toilet's facilities for } \\
\text { elder people and } \\
\text { disabled Patients (if } \\
\text { occur) }\end{array}$} & 2 & 9 & 12 & 16 & 8 & \multirow[b]{2}{*}{3.40} & \multirow[b]{2}{*}{1.12} \\
\hline & & $4.26 \%$ & $19.15 \%$ & $25.53 \%$ & $34.04 \%$ & $17.02 \%$ & & \\
\hline \multirow[t]{2}{*}{4} & \multirow{2}{*}{$\begin{array}{l}\text { High standards of room } \\
\text { tidiness and } \\
\text { arrangement }\end{array}$} & 3 & 5 & 1 & 25 & 13 & \multirow{2}{*}{3.85} & \multirow[b]{2}{*}{1.14} \\
\hline & & $6.38 \%$ & $10.64 \%$ & $2.13 \%$ & $53.19 \%$ & $27.66 \%$ & & \\
\hline \multirow[t]{2}{*}{5} & \multirow{2}{*}{$\begin{array}{l}\text { Availability and good } \\
\text { condition of Equipment } \\
\text { and patient amenities }\end{array}$} & 6 & 9 & 7 & 17 & 8 & \multirow[b]{2}{*}{3.26} & \multirow[b]{2}{*}{1.31} \\
\hline & & $12.77 \%$ & $19.15 \%$ & $14.89 \%$ & $36.17 \%$ & $17.02 \%$ & & \\
\hline 6. & $\begin{array}{l}\text { Daily garbage and } \\
\text { waste Handling }\end{array}$ & $\begin{array}{c}6 \\
12.77 \%\end{array}$ & $\begin{array}{c}3 \\
6.38 \%\end{array}$ & $\begin{array}{c}4 \\
8.51 \%\end{array}$ & $\begin{array}{c}18 \\
38.30 \%\end{array}$ & $\begin{array}{c}16 \\
34.04 \%\end{array}$ & 3.74 & 1.34 \\
\hline 7. & $\begin{array}{l}\text { Comfortable bed with } \\
\text { adequate capabilities }\end{array}$ & $\begin{array}{c}6 \\
12.77 \%\end{array}$ & $\begin{array}{c}8 \\
17.02 \%\end{array}$ & $\frac{4}{8.51 \%}$ & $\begin{array}{c}14 \\
29.79 \%\end{array}$ & $\begin{array}{c}15 \\
31.91 \%\end{array}$ & 3.51 & 1.43 \\
\hline \multirow[t]{2}{*}{8} & \multirow{2}{*}{$\begin{array}{l}\text { Acceptable Bed sheets' } \\
\text { quality, condition and } \\
\text { cleanliness }\end{array}$} & 2 & 3 & 5 & 17 & 20 & \multirow[b]{2}{*}{4.06} & \multirow[b]{2}{*}{1.09} \\
\hline & & $4.26 \%$ & $6.38 \%$ & $10.64 \%$ & $36.17 \%$ & $42.55 \%$ & & \\
\hline \multirow[t]{2}{*}{9 . } & \multirow{2}{*}{$\begin{array}{l}\text { Re-making and } \\
\text { changing the bed on a } \\
\text { daily and regular basis }\end{array}$} & 2 & 7 & 6 & 18 & 14 & & \\
\hline & & $4.26 \%$ & $14.89 \%$ & $12.76 \%$ & $38.30 \%$ & $29.79 \%$ & 3.74 & 1.17 \\
\hline & & ean of Qu & ity of Pati & Room & & & & \\
\hline & & Groomin & and Perfor & nce of $\mathrm{Ho}$ & keeping $\mathrm{S}$ & & & \\
\hline 1. & Acceptable personal & 5 & 6 & 3 & 21 & 12 & & \\
\hline & hygiene and grooming & $10.64 \%$ & $12.77 \%$ & $6.38 \%$ & $44.68 \%$ & $25.53 \%$ & 3.62 & 1.29 \\
\hline 2. & Courteous attitude and & 4 & 8 & 5 & 20 & 10 & & \\
\hline & behavior & $8.51 \%$ & $17.02 \%$ & $10.64 \%$ & $42.55 \%$ & $21.28 \%$ & 3.51 & 1.25 \\
\hline 3. & Immediate response to & 9 & 12 & 7 & 14 & 5 & & \\
\hline & $\begin{array}{l}\text { patient requests and } \\
\text { needs }\end{array}$ & $19.15 \%$ & $25.53 \%$ & $14.89 \%$ & $29.79 \%$ & $10.64 \%$ & 2.87 & 1.33 \\
\hline & Regular punctuality and & 5 & 7 & 4 & 19 & 12 & 3.55 & 1.32 \\
\hline & commitment & $10.64 \%$ & $14.89 \%$ & $8.51 \%$ & $40.43 \%$ & $25.53 \%$ & 3.53 & 1.32 \\
\hline & High level of cleansing & 3 & 4 & 6 & 23 & 11 & & \\
\hline & and sanitizing processes & $6.38 \%$ & $8.51 \%$ & $12.77 \%$ & $48.94 \%$ & $23.40 \%$ & 3.14 & 1.11 \\
\hline 6. & Immediate and full & 5 & 8 & 11 & 16 & 7 & & \\
\hline & $\begin{array}{l}\text { Handling of patients' } \\
\text { requests and complaints }\end{array}$ & $10.64 \%$ & $17.02 \%$ & $23.41 \%$ & $34.04 \%$ & $14.89 \%$ & 3.26 & 1.22 \\
\hline & Mean of Gro & ing and $\mathrm{F}$ & formance & Housekee & Staff & & & \\
\hline & & Med & 1 Services & bllow up a & Facilities & & & \\
\hline 1. & Immediate reply to & 6 & 8 & 5 & 15 & 13 & & \\
\hline & $\begin{array}{l}\text { urgent patient medical } \\
\text { call/request (if } \\
\text { happened) }\end{array}$ & $12.77 \%$ & $17.02 \%$ & $10.64 \%$ & $31.91 \%$ & $27.66 \%$ & 3.44 & 1.39 \\
\hline 2. & Daily and regular & 5 & 8 & 5 & 17 & 12 & & \\
\hline & $\begin{array}{l}\text { Medical checkup and } \\
\text { follow up }\end{array}$ & $10.64 \%$ & $17.02 \%$ & $10.64 \%$ & $36.17 \%$ & $25.53 \%$ & 3.49 & 1.33 \\
\hline 3. & Acceptable & 7 & 9 & 13 & 12 & 6 & & \\
\hline & $\begin{array}{l}\text { performance of nursing } \\
\text { staff }\end{array}$ & $14.89 \%$ & $19.15 \%$ & $27.66 \%$ & $25.53 \%$ & $12.77 \%$ & 3.02 & 1.26 \\
\hline 4. & Availability of modern & 4 & 7 & 3 & 22 & 11 & & \\
\hline & $\begin{array}{l}\text { devices, tools and } \\
\text { amenities }\end{array}$ & $8.51 \%$ & $14.89 \%$ & $6.39 \%$ & $46.81 \%$ & $23.40 \%$ & 3.62 & 1.24 \\
\hline & Mean of & edical Ser & ces, Follo & $\mathrm{p}$ and Fac & & & & \\
\hline & & & Food Q & tity and $M$ & & & & \\
\hline & $\begin{array}{l}\text { Available program for } \\
\text { identifying patients' }\end{array}$ & 8 & 11 & 13 & 9 & 6 & & \\
\hline & $\begin{array}{l}\text { food and beverage } \\
\text { needs, desires and } \\
\text { special requirements }\end{array}$ & $17.02 \%$ & $23.40 \%$ & $27.66 \%$ & $19.15 \%$ & $12.77 \%$ & 2.87 & 1.27 \\
\hline
\end{tabular}


International Journal of Heritage, Tourism and Hospitality Vol. (12), No. (2/2), September, 2018 By: Faculty of Tourism and Hotels, Fayoum University, Egypt

\begin{tabular}{|c|c|c|c|c|c|c|c|}
\hline \multirow{2}{*}{$\begin{array}{l}\text { 2. Adequate number of } \\
\text { offered daily food } \\
\text { meals }\end{array}$} & 3 & 6 & 4 & 22 & 12 & \multirow{2}{*}{3.72} & \multirow{2}{*}{1.17} \\
\hline & $6.38 \%$ & $12.77 \%$ & $8.51 \%$ & $46.81 \%$ & $25.53 \%$ & & \\
\hline \multirow{2}{*}{$\begin{array}{l}\text { Satisfactory food taste, } \\
\text { flavor, texture, shape } \\
\text { and presentation }\end{array}$} & 5 & 7 & 6 & 18 & 11 & \multirow[b]{2}{*}{3.49} & \multirow[b]{2}{*}{1.30} \\
\hline & $10.64 \%$ & $14.89 \%$ & $12.77 \%$ & $38.30 \%$ & $23.40 \%$ & & \\
\hline \multirow{2}{*}{$\begin{array}{l}\text { Appropriate } \\
\text { temperature of served } \\
\text { food }\end{array}$} & 4 & 5 & 6 & 22 & 10 & \multirow{2}{*}{3.62} & \multirow[b]{2}{*}{1.19} \\
\hline & $8.51 \%$ & $10.64 \%$ & $12.76 \%$ & $46.81 \%$ & $21.28 \%$ & & \\
\hline \multirow{2}{*}{$\begin{array}{l}\text { Safe food with no cases } \\
\text { of food poisoning nor } \\
\text { food contamination } \\
\text { problems }\end{array}$} & 0 & 0 & 0 & 32 & 15 & \multirow{2}{*}{4.32} & \multirow{2}{*}{0.47} \\
\hline & $0.00 \%$ & $0.00 \%$ & $0.00 \%$ & $68.09 \%$ & $31.91 \%$ & & \\
\hline \multirow{2}{*}{$\begin{array}{l}\text { 6. Suitable dietary and } \\
\text { nutritious food } \\
\text { matching disease/ }\end{array}$} & 2 & 4 & 5 & 13 & 23 & \multirow[b]{2}{*}{4.09} & \multirow[b]{2}{*}{1.16} \\
\hline & $4.26 \%$ & $8.51 \%$ & $10.63 \%$ & $27.66 \%$ & $48.94 \%$ & & \\
\hline \multirow{2}{*}{ 7. Enough Menu variety } & 10 & 16 & 9 & 7 & 5 & \multirow{2}{*}{2.59} & \multirow{2}{*}{1.28} \\
\hline & $21.28 \%$ & $34.04 \%$ & $19.15 \%$ & $14.89 \%$ & $10.64 \%$ & & \\
\hline $8 \quad$ Adequate food portion & 9 & 8 & 17 & 7 & 6 & & \\
\hline 8. Adequate rood portion & $19.15 \%$ & $17.02 \%$ & $36.17 \%$ & $14.89 \%$ & $12.77 \%$ & 2.85 & 1.21 \\
\hline & ean of Fo & Quality a & Menu & & & & \\
\hline & & d Service & d Cafeteri & cility & & & \\
\hline 1. Punctuality in serving & 8 & 9 & 6 & 18 & 6 & & \\
\hline Meals & $17.02 \%$ & $19.15 \%$ & $12.76 \%$ & $38.30 \%$ & $12.77 \%$ & 3.11 & 1.34 \\
\hline 2. High quality of food & 6 & 7 & 8 & 10 & 16 & & \\
\hline $\begin{array}{l}\text { service tools and } \\
\text { equipment }\end{array}$ & $12.77 \%$ & $14.89 \%$ & $17.02 \%$ & $21.28 \%$ & $34.04 \%$ & 3.49 & 1.43 \\
\hline 3. Correct packing of food & 6 & 9 & 15 & 12 & 5 & 302 & 110 \\
\hline items & $12.77 \%$ & $19.15 \%$ & $31.91 \%$ & $25.53 \%$ & $10.64 \%$ & 5.02 & 1.19 \\
\hline 4. Acceptable sanitizing & 5 & 13 & 5 & 15 & 9 & & \\
\hline $\begin{array}{l}\text { condition of food } \\
\text { service tools and } \\
\text { equipment }\end{array}$ & $10.64 \%$ & $27.66 \%$ & $10.64 \%$ & $31.91 \%$ & $19.15 \%$ & 3.21 & 1.33 \\
\hline 5. Availability of cafeteria & 2 & 5 & 0 & 15 & 25 & & \\
\hline $\begin{array}{l}\text { service at any time (for } \\
\text { non-patients) }\end{array}$ & $4.26 \%$ & $10.64 \%$ & $0.00 \%$ & $31.91 \%$ & $53.19 \%$ & 4.19 & 1.15 \\
\hline Mean & f Food Se & ce and $\mathrm{C}$ & eria Facil & & & & \\
\hline & & formance & Food Serv & Staff & & & \\
\hline 1. Punctual and committed & 0 & 7 & 8 & 18 & 14 & & \\
\hline service Staff & $0.00 \%$ & $14.89 \%$ & $17.02 \%$ & $38.30 \%$ & $29.79 \%$ & 3.83 & 1.03 \\
\hline 2. Professional and skillful & 7 & 9 & 14 & 6 & 11 & & \\
\hline $\begin{array}{l}\text { service staff with least } \\
\text { number of serving } \\
\text { errors }\end{array}$ & $14.89 \%$ & $19.15 \%$ & $29.79 \%$ & $12.77 \%$ & $23.40 \%$ & 3.11 & 1.37 \\
\hline 3. Full Menu knowledge & 5 & 5 & 7 & 18 & 12 & 3.57 & 1.28 \\
\hline and awareness & $10.64 \%$ & $10.64 \%$ & $14.89 \%$ & $38.30 \%$ & $25.53 \%$ & 5.51 & 1.20 \\
\hline 4. Courteous attitude and & 4 & 9 & 5 & 19 & 10 & 3.47 & 127 \\
\hline behavior & $8.51 \%$ & $19.15 \%$ & $10.63 \%$ & $40.43 \%$ & $21.28 \%$ & 3.41 & 1.21 \\
\hline 5 Safe working hahits & 2 & 1 & 7 & 24 & 13 & 396 & 005 \\
\hline 5. saie working nabits & $4.26 \%$ & $2.13 \%$ & $14.89 \%$ & $51.06 \%$ & $27.66 \%$ & 3.90 & 0.95 \\
\hline 6. Acceptable personal & 5 & 6 & 5 & 17 & 14 & & \\
\hline hygiene and grooming & $10.64 \%$ & $12.77 \%$ & $10.63 \%$ & $36.17 \%$ & $29.79 \%$ & .62 & 1.33 \\
\hline 7. Competent & 10 & 15 & 8 & 11 & 3 & & \\
\hline $\begin{array}{l}\text { communication and } \\
\text { language skills (for } \\
\text { Non-Arab patients) }\end{array}$ & $21.28 \%$ & $31.91 \%$ & $17.03 \%$ & $23.40 \%$ & $6.38 \%$ & 2.62 & 1.24 \\
\hline 8. Handling patient & 5 & 12 & 7 & 14 & 9 & 21 & 132 \\
\hline complaints thoroughly & $10.64 \%$ & $25.53 \%$ & $14.89 \%$ & $29.79 \%$ & $19.15 \%$ & 3.21 & 1.32 \\
\hline Mean & f Perform & ce of Foo & ervice Sta & & & & \\
\hline & spital $\mathrm{Sp}$ & ellness & Therapy & rams (If & cur) & & \\
\hline 1. Health Club and Spa & 0 & 0 & 0 & 0 & 0 & & \\
\hline Services offered to the & $0.00 \%$ & $0.00 \%$ & $0.00 \%$ & $0.00 \%$ & $0.00 \%$ & 0.0 & 0.0 \\
\hline
\end{tabular}


International Journal of Heritage, Tourism and Hospitality Vol. (12), No. (2/2), September, 2018 By: Faculty of Tourism and Hotels, Fayoum University, Egypt

\begin{tabular}{|c|c|c|c|c|c|c|c|c|}
\hline \multirow{3}{*}{\multicolumn{2}{|c|}{$\begin{array}{ll}\text { patient and companions } \\
\text { 2. } & \text { Fitness and Gym } \\
& \text { Program offered to the } \\
\text { patient and companions }\end{array}$}} & & \multirow[b]{2}{*}{0} & \multirow[b]{2}{*}{0} & \multirow[b]{2}{*}{0} & \multirow[b]{2}{*}{0} & \multirow[b]{3}{*}{0.0} & \multirow[b]{3}{*}{0.0} \\
\hline & & \multirow{2}{*}{$\frac{0}{0.00 \%}$} & & & & & & \\
\hline & & & $0.00 \%$ & $0.00 \%$ & $0.00 \%$ & $0.00 \%$ & & \\
\hline \multirow[t]{2}{*}{3} & \multirow{2}{*}{$\begin{array}{l}\text { Recommended walking } \\
\text { or running programs }\end{array}$} & 31 & 6 & 3 & 5 & 2 & \multirow{2}{*}{1.74} & \multirow{2}{*}{1.22} \\
\hline & & $65.96 \%$ & $12.77 \%$ & $6.37 \%$ & $10.64 \%$ & $4.26 \%$ & & \\
\hline \multicolumn{7}{|c|}{ Mean of Hospital Spa, Wellness and Therapy Programs } & \multicolumn{2}{|c|}{1.74} \\
\hline \multicolumn{9}{|c|}{$\begin{array}{l}\text { Hospital Entertainment and Patient Country Tour/Visit Programs } \\
\text { (If Occur during or after treatment) }\end{array}$} \\
\hline \multirow{2}{*}{\multicolumn{2}{|c|}{$\begin{array}{l}\text { 1. Acceptable arrangement } \\
\text { of patient's tour and } \\
\text { visits to tourist sites }\end{array}$}} & 0 & 0 & 0 & 0 & 0 & \multirow[b]{2}{*}{0.0} & \multirow[b]{2}{*}{0.0} \\
\hline & & $0.00 \%$ & $0.00 \%$ & $0.00 \%$ & $0.00 \%$ & $0.00 \%$ & & \\
\hline \multirow{2}{*}{\multicolumn{2}{|c|}{$\begin{array}{l}\text { Satisfactory } \\
\text { transportation Services } \\
\text { and good choices of } \\
\text { tourist sites }\end{array}$}} & 0 & 0 & 0 & 0 & 0 & \multirow{2}{*}{0.0} & \multirow{2}{*}{0.0} \\
\hline & & $0.00 \%$ & $0.00 \%$ & $0.00 \%$ & $0.00 \%$ & $0.00 \%$ & & \\
\hline & \multirow{2}{*}{$\begin{array}{l}\text { Provision of tour leader } \\
\text { and tour guide services }\end{array}$} & 0 & 0 & 0 & 0 & 0 & \multirow{2}{*}{0.0} & \multirow{2}{*}{0.0} \\
\hline & & $0.00 \%$ & $0.00 \%$ & $0.00 \%$ & $0.00 \%$ & $0.00 \%$ & & \\
\hline \multicolumn{7}{|c|}{ Mean of Hospital Entertainment and Patient Country Tour/Visit Programs } & \multicolumn{2}{|c|}{0.0} \\
\hline \multicolumn{9}{|c|}{ Dry Clean and Laundry Facilities and Services (if exist) } \\
\hline & Immediate response to & 26 & 15 & 2 & 2 & 2 & & \\
\hline & $\begin{array}{l}\text { orders with punctuality } \\
\text { of delivering }\end{array}$ & $55.32 \%$ & $31.91 \%$ & $4.25 \%$ & $4.26 \%$ & $4.26 \%$ & 1.70 & 1.04 \\
\hline 2 & High Quality of & 15 & 14 & 6 & 7 & 5 & & \\
\hline & $\begin{array}{l}\text { washing and dry } \\
\text { Cleaning }\end{array}$ & $31.91 \%$ & $29.79 \%$ & $12.77 \%$ & $14.89 \%$ & $10.64 \%$ & 2.43 & 1.36 \\
\hline & Mean of D & Clean an & aundry $\mathrm{F}$ & ities and & ices & & & \\
\hline & Com & nions' ( & -Patient C & sts) Accol & dation (I & ailable) & & \\
\hline & Availability of enough & 12 & 20 & 3 & 8 & 4 & & \\
\hline & number of rooms & $25.53 \%$ & $42.55 \%$ & $6.39 \%$ & $17.02 \%$ & $8.51 \%$ & 2.40 & 1.28 \\
\hline & Satisfactory cleanliness & 8 & 9 & 5 & 18 & 7 & & \\
\hline & $\begin{array}{l}\text { and tidiness of } \\
\text { companions' Housing }\end{array}$ & $17.02 \%$ & $19.15 \%$ & $10.64 \%$ & $38.30 \%$ & $14.89 \%$ & 3.15 & 1.37 \\
\hline & High quality of food & 11 & 10 & 10 & 7 & 9 & & \\
\hline & $\begin{array}{l}\text { and beverage services } \\
\text { offered to companions }\end{array}$ & $23.40 \%$ & $21.28 \%$ & $21.28 \%$ & $14.89 \%$ & $19.15 \%$ & 2.85 & 1.44 \\
\hline 4 & Adeguate room Snace & 21 & 8 & 4 & 9 & 5 & 234 & 148 \\
\hline & Adequate room Space & $44.68 \%$ & $17.02 \%$ & $8.51 \%$ & $19.15 \%$ & $10.64 \%$ & 2.34 & 1.48 \\
\hline & Available telephone call & 19 & 8 & 7 & 9 & 4 & & \\
\hline & services & $40.43 \%$ & $17.02 \%$ & $14.89 \%$ & $19.15 \%$ & $8.51 \%$ & 2.38 & 1.41 \\
\hline & Mean of Com & nions' $(\mathrm{N}$ & -Patient C & sts) Acco & dation & & & \\
\hline
\end{tabular}

From the data illustrated in Table (11), the following findings can be illustrated:

HSF 1 - Hospital reservation and registration procedures

In first element "well arranged of a patient's visit", the mean is 3.96, suggesting agreeing response, and in the second element "acceptable companion housing reservation", the mean is 2.89 , suggesting relatively agree response, and in the third element "good management of medical tourism program", the mean is 1.96, suggesting disagree response; the Std. Deviation is $1.27,1.43$ and 0.91 respectively, suggesting dispersion answers. The mean of elements is 2.94 , suggesting relatively agree response

\section{HSF 2 - Hospital internet services}

In first element "proficient e-marketing facilities", the mean is 2.74, suggesting relatively agree response, and in the second element "professional on-line communication \& e-reservation", the mean is 2.74 , suggesting relatively agree response; the Std. Deviation is 1.39 , and 1.58 respectively, suggesting dispersion answers. The mean of elements is 2.74 , suggesting relatively agree response. 


\section{HSF 3 - Travel and transportation services}

In first element "prearranged flight tickets facilities by hospitals", the mean is 2.15 , suggesting disagree response, and in the second element "well-organized meet and assist services at the airport", the mean is 2.51 , suggesting disagree response, and in the third element "well-managed transportation services from airport to the hospital", the mean is 3.66, suggesting agreeing response; the Std. Deviation is 1.16, 1.27 and 1.34 respectively, suggesting dispersion answers. The mean of elements is 2.77, suggesting relatively agree response.

\section{HSF 4 - Hospital welcoming and accommodation services}

In first element "professional greeting and welcoming procedures upon arrival", the mean is 3.74, suggesting agreeing response, and in the second element "clarification of payment methods during registration", the mean is 3.47, suggesting agreeing response, and in the third element "professional hospitality skills and performance of reception staff", the mean is 3.47, suggesting agreeing response, and in the fourth element "appropriate registration time-span", the mean is 2.89 , suggesting relatively agree response, and in the fifth element "adequate lobby space for patient and companions waiting", the mean is 3.28, suggesting relatively agree response, and in the sixth element "standardized procedures of guiding the patient to the room", the mean is 3.57, suggesting agreeing response, and in the seventh element "systematic procedures of accommodating companions", the mean is 2.70 , suggesting relatively agree response; the Std. Deviation is 1.19, 1.23, 1.46, 1.22, 1.29, 1.28 and 1.44 respectively suggesting dispersion answers. The mean of elements is 3.30, suggesting relatively agree response.

\section{HSF 5 - Quality of patient room}

In first element "high standards of room cleanliness and sanitation", the mean is 3.87 , suggesting agreeing response, and in the second element "high standards of toilets sanitization and sterilization", the mean is 3.83, suggesting agreeing response, and in the third element "available room and toilet facilities for older people and disabled Patients", the mean is 3.40, suggesting relatively agree response, and in the fourth element "high standards of room tidiness and arrangement", the mean is 3.85 , suggesting agreeing response, and in the fifth element "availability and good condition of equipment and patient amenities", the mean is 3.26, suggesting relatively agree response, and in the sixth element "daily garbage and waste handling", the mean is 3.74, suggesting agreeing response, and in the seventh element "comfortable bed with adequate capabilities", the mean is 3.51, suggesting agreeing response, and in the eighth element "acceptable bed sheets' quality, condition and cleanliness", the mean is 4.06, suggesting agreeing response, and in the ninth element "re-making and changing the bed on a daily and regular basis", the mean is 3.74 , suggesting agreeing response; the Std. Deviation is 1.13, 0.99, 1.12, 1.14, 1.31, 1.34, 1.43, 1.09 and 1.17 respectively suggesting dispersion answers. The mean of elements is 3.70 , suggesting agreeing response.

\section{HSF 6 - Grooming and performance of housekeeping staff}

In first element "acceptable personal hygiene and grooming", the mean is 3.62, suggesting agreeing response, and in the second element "courteous attitude and behavior", the mean is 3.51, suggesting agreeing response, and in the third element "immediate response to patient requests and needs", the mean is 2.87 , suggesting relatively agree response, and in the fourth element "regular punctuality and 
commitment", the mean is 3.55 , suggesting agreeing response, and in the fifth element "high level of cleansing and sanitizing processes", the mean is 3.74, suggesting agreeing response, and in the sixth element "immediate and full handling of patients' requests and complaints", the mean is 3.26 , suggesting relatively agree response; the Std. Deviation is $1.29,1.25,1.33,1.32,1.11$ and 1.22 respectively suggesting dispersion answers. The mean of elements is 3.43, suggesting agreeing response.

\section{HSF 7 - Medical services follow up and facilities:}

In first element "immediate reply to urgent patient medical call/request", the mean is 3.44, suggesting agreeing response, and in the second element "daily and regular medical checkup and follow up", the mean is 3.49, suggesting agreeing response, and in the third element "acceptable performance of nursing staff", the mean is 3.02, suggesting relatively agree response, and in the fourth element "availability of modern and sanitized medical devices, tools and amenities", the mean is 3.62, suggesting agreeing response; the Std. Deviation is 1.39, 1.33, 1.26 and 1.24 respectively suggesting dispersion answers. The mean of elements is 3.39 , suggesting relatively agree response.

\section{HSF 8 - Food quality and menu}

In first element "available program for identifying patients' food and beverage needs, desires and special requirements", the mean is 2.87 , suggesting relatively agree response, and in the second element "adequate number of offered daily food meals", the mean is 3.72, suggesting agreeing response, and in the third element "satisfactory food taste, flavor, texture, shape and presentation", the mean is 3.49, suggesting agreeing response, and in the fourth element "appropriate temperature of served food", the mean is 3.62, suggesting agreeing response, and in the fifth element "safe food with no cases of food poisoning nor food contamination problems", the mean is 4.32, suggesting relatively agree response, and in the sixth element "suitable dietary and nutritious food matching disease/ treatment regime", the mean is 4.09, suggesting agreeing response, and in the seventh element "enough Menu variety", the mean is 2.59 , suggesting disagree response, and in the eighth element "adequate food portion", the mean is 2.85 , suggesting relatively agree response; the Std. Deviation is 1.27, $1.17,1.30,1.19,0.47,1.16,1.28$ and 1.27 respectively suggesting dispersion answers, except the fifth element which suggesting homogeneity answers. The mean of elements is 3.44 , suggesting agreeing response.

\section{HSF 9 - Food service and cafeteria facility}

In first element "punctuality in serving meals", the mean is 3.11, suggesting relatively agree response, and in the second element "high quality of food service tools and equipment", the mean is 3.49 , suggesting agreeing response, and in the third element "correct packing of food items", the mean is 3.02, suggesting relatively agree response, and in the fourth element "acceptable sanitizing condition of food service tools and equipment", the mean is 3.21, suggesting relatively agree response, and in the fifth element "availability of cafeteria service at any time (for non-patients)", the mean is 4.19, suggesting agreeing response; the Std. Deviation is 1.34, 1.43, 1.19, 1.33 and 1.15 respectively suggesting dispersion answers. The mean of elements is 3.40, suggesting relatively agree response.

\section{HSF 10 - Performance of food service staff}

In first element "punctual and committed service Staff", the mean is 3.83, suggesting agreeing response, and in the second element "professional and skillful service staff 
with least number of serving errors", the mean is 3.11, suggesting relatively agree response, and in the third element "full menu knowledge and awareness", the mean is 3.57, suggesting agreeing response, and in the fourth element "courteous attitude and behavior", the mean is 3.47 , suggesting agreeing response, and in the fifth element "safe working habits", the mean is 3.96, suggesting agreeing response, and in the sixth element "acceptable personal hygiene and grooming", the mean is 3.62, suggesting agreeing response, and in the seventh element "competent communication and language skills (for Non-Arab patients)", the mean is 2.62, suggesting relatively agree response, and in the eighth element "handling patient complaints thoroughly", the mean is 3.21, suggesting relatively agree response; the Std. Deviation is 1.03, 1.37, $1.28,1.27,0.95,1.33,1.24$ and 1.32 respectively suggesting dispersion answers. The mean of elements is 3.42 , suggesting agreeing response.

\section{HSF 11 - Hospital spa, wellness and therapy programs}

In first element "health club and spa services offered to the patient and companions", and in the second element "fitness and gym program offered to the patient and companions", there are no responses, and in the third element "recommended walking or running programs", the mean is 1.74 , suggesting Totally disagree response, the Std. Deviation is 1.22 respectively suggesting dispersion answers. The mean of elements is 1.74 , suggesting totally disagree response.

HSF 12- Hospital entertainment and patient country tour/visit programs (if occur during or after treatment)

In first element "acceptable arrangement of patient's tour and visits to tourist sites" and in the second element "satisfactory transportation services and good choices of tourist sites", and in the third element "provision of tour leader and tour guide services", there are no responses.

\section{HSF 13 - Dry clean and laundry facilities and services (if exist)}

In first element "immediate response to dry clean and laundry orders with punctuality of delivering", the mean is 1.70 , suggesting totally disagree response, and in the second element "high quality of washing and dry cleaning", the mean is 2.43, suggesting disagree response; the Std. Deviation is 1.04 and 1.36 respectively suggesting dispersion answers. The mean of elements is 2.06, suggesting disagree response.

\section{HSF 14 - Companions' (non-patient guests) accommodation (if available)}

In first element "availability of enough number of rooms", the mean is 2.40 , suggesting disagree response, and in the second element "satisfactory cleanliness and tidiness of companions' housing", the mean is 3.15, suggesting relatively agree response, and in the third element "high quality of food and beverage services offered to companions", the mean is 2.85 , suggesting relatively agree response, and in the fourth element "adequate room Space", the mean is 2.34, suggesting disagree response, and in the fifth element "available telephone call services", the mean is 2.38, suggesting disagree response; the Std. Deviation is $1.28,1.37,1.44,1.48$ and 1.41 respectively suggesting dispersion answers. The mean of elements is 2.63 , suggesting relatively agree response. 
International Journal of Heritage, Tourism and Hospitality Vol. (12), No. (2/2), September, 2018 By: Faculty of Tourism and Hotels, Fayoum University, Egypt

Part four: Overall evaluation of the comprehensive medical visit to Egypt (in general) and to the hospital (in specific)

Table12: Patients' answers regarding the medical visit to Egypt and hospital

\begin{tabular}{|c|c|c|c|c|c|c|c|}
\hline \multirow[t]{2}{*}{ Criteria of Evaluation } & 1 & 2 & 3 & 4 & 5 & \multirow[t]{2}{*}{ Mean } & \multirow{2}{*}{$\begin{array}{c}\text { Std. } \\
\text { Deviation }\end{array}$} \\
\hline & $\begin{array}{l}\text { Totally } \\
\text { disagree }\end{array}$ & Disagree & $\begin{array}{c}\text { Relatively } \\
\text { agree }\end{array}$ & Agree & $\begin{array}{c}\text { Strongly } \\
\text { agree }\end{array}$ & & \\
\hline \multirow[t]{2}{*}{ 1. Acc } & 5 & 6 & 16 & 11 & 9 & \multirow[t]{2}{*}{3.28} & \multirow[t]{2}{*}{1.23} \\
\hline & $10.64 \%$ & $12.77 \%$ & $34.04 \%$ & $23.40 \%$ & $19.15 \%$ & & \\
\hline \multirow{2}{*}{$\begin{array}{ll}\text { 2. Proficient overall } \\
\text { medical visit to the } \\
\text { hospital }\end{array}$} & 4 & 8 & 18 & 12 & 5 & \multirow[t]{2}{*}{3.13} & \multirow[t]{2}{*}{1.09} \\
\hline & $8.51 \%$ & $17.02 \%$ & $38.30 \%$ & $25.53 \%$ & $10.64 \%$ & & \\
\hline \multirow{2}{*}{$\begin{array}{l}\text { 3. The overall hospital } \\
\text { management and } \\
\text { administration is up to } \\
\text { the standard }\end{array}$} & 5 & 7 & 15 & 9 & 11 & \multirow[t]{2}{*}{3.30} & \multirow[t]{2}{*}{1.28} \\
\hline & $10.64 \%$ & $14.89 \%$ & $31.92 \%$ & $19.15 \%$ & $23.40 \%$ & & \\
\hline \multirow{3}{*}{$\begin{array}{l}\text { 4. You will recommend } \\
\text { your friends/relatives } \\
\text { to experience the } \\
\text { medical tourism visit } \\
\text { to the hospital (if } \\
\text { needed in the future) }\end{array}$} & 2 & 6 & 17 & 10 & 12 & \multirow[t]{3}{*}{3.51} & \multirow[t]{3}{*}{1.14} \\
\hline & & & & & & & \\
\hline & $4.26 \%$ & $12.77 \%$ & $36.16 \%$ & $21.28 \%$ & $25.53 \%$ & & \\
\hline \multicolumn{6}{|c|}{ Mean of Overall Evaluation about the Comprehensive Medical Visit to Egypt \& hospital } & \multicolumn{2}{|c|}{3.30} \\
\hline
\end{tabular}

As shown in Table (12), In first element "acceptable overall medical tourism program in Egypt", the mean is 3.28, suggesting relatively agree response, and in the second element "proficient overall medical visit to the hospital", the mean is 3.13 , suggesting relatively agree response, and in the third element "the overall hospital management and administration is up to the standard", the mean is 3.30, suggesting relatively agree response, and in the fourth element "you will recommend your friends/relatives to experience the medical tourism visit to the hospital (if needed in the future)", the mean is 3.51, suggesting agreeing response; the Std. Deviation is 1.23, 1.09, 1.28 and 1.14 respectively suggesting dispersion answers. The mean of elements is 3.30, suggesting relatively agree response.

Table 13: Pearson Correlation Matrix for relationship between study variables

\begin{tabular}{|c|c|c|c|c|c|c|c|c|c|c|c|c|c|c|}
\hline $\begin{array}{c}\text { Variabl } \\
\text { es }\end{array}$ & $\begin{array}{c}\text { HSF } \\
1\end{array}$ & $\begin{array}{c}\text { HSF } \\
2\end{array}$ & $\begin{array}{c}\text { HSF } \\
3\end{array}$ & $\begin{array}{c}\text { HSF } \\
4\end{array}$ & $\begin{array}{c}\text { HSF } \\
5\end{array}$ & $\begin{array}{c}\text { HSF } \\
6\end{array}$ & $\begin{array}{c}\text { HSF } \\
7\end{array}$ & $\begin{array}{c}\text { HSF } \\
8\end{array}$ & $\begin{array}{c}\text { HSF } \\
9\end{array}$ & $\begin{array}{c}\text { HSF } \\
10\end{array}$ & $\begin{array}{c}\text { HSF } \\
11\end{array}$ & $\begin{array}{c}\text { HSF } \\
13\end{array}$ & $\begin{array}{c}\text { HSF } \\
14\end{array}$ & $\begin{array}{c}\text { Patients' } \\
\text { satisfacti } \\
\text { on }\end{array}$ \\
\hline HSF1 & 1 & $.953^{* *}$ & $.965^{* *}$ & $.985^{* *}$ & $.958^{* *}$ & $.978^{* *}$ & $.972^{* *}$ & $.983^{* *}$ & $.979^{* *}$ & $.981^{* *}$ & $.760^{* *}$ & $.891^{* *}$ & $.961^{* *}$ & $.981^{* *}$ \\
\hline HSF2 & & 1 & $.939^{* *}$ & $.928^{* *}$ & $.878^{* *}$ & $.905^{* *}$ & $.910^{* *}$ & $.935^{* *}$ & $.915^{* *}$ & $.932^{* *}$ & $.851^{* *}$ & $.935^{* *}$ & $.979^{* *}$ & $.953^{* *}$ \\
\hline HSF3 & & & 1 & $.967^{* *}$ & $.929^{* *}$ & $.956^{* *}$ & $.952^{* *}$ & $.971^{* *}$ & $.923^{* *}$ & $.959^{* *}$ & $.833^{* *}$ & $.916^{* *}$ & $.955^{* *}$ & $.966^{* *}$ \\
\hline HSF4 & & & & 1 & $.982^{* *}$ & $.993^{* *}$ & $.991^{* *}$ & $.993^{* *}$ & $.978^{* *}$ & $.991^{* *}$ & $.720^{* *}$ & $.847^{* *}$ & $.939^{* * *}$ & $.977^{* *}$ \\
\hline HSF5 & & & & & 1 & $.982^{* *}$ & $.975^{* *}$ & $.980^{* *}$ & $.971^{* *}$ & $.979^{* *}$ & $.647^{* *}$ & $.779^{* *}$ & $.887^{* * *}$ & $.962^{* *}$ \\
\hline HSF6 & & & & & & 1 & $.993^{* *}$ & $.989^{* *}$ & $.977^{* *}$ & $.989^{* *}$ & $.687^{* *}$ & $.826^{* *}$ & $.918^{* * *}$ & $.972^{* * *}$ \\
\hline HSF7 & & & & & & & 1 & $.987^{* *}$ & $.978^{* *}$ & $.990^{* *}$ & $.688^{* *}$ & $.830^{* *}$ & $.925^{* *}$ & $.962^{* *}$ \\
\hline HSF8 & & & & & & & & 1 & $.975^{* *}$ & $.993^{* *}$ & $.750^{* *}$ & $.868^{* *}$ & $.949^{* *}$ & $.982^{* *}$ \\
\hline HSF9 & & & & & & & & & 1 & $.979^{* *}$ & $.683^{* *}$ & $.834^{* *}$ & $.933^{* * *}$ & $.959^{* *}$ \\
\hline HSF10 & & & & & & & & & & 1 & $.727^{* *}$ & $.850^{* *}$ & $.943^{* * *}$ & $.977^{* *}$ \\
\hline HSF11 & & & & & & & & & & & 1 & $.923^{* *}$ & $.860^{* *}$ & $.774^{* *}$ \\
\hline
\end{tabular}


International Journal of Heritage, Tourism and Hospitality Vol. (12), No. (2/2), September, 2018 By: Faculty of Tourism and Hotels, Fayoum University, Egypt

\begin{tabular}{|c|l|l|l|l|l|l|l|l|l|l|l|l|c|c|}
\hline HSF13 & & & & & & & & & & & & 1 & $.950^{* *}$ & $.883^{* *}$ \\
\hline HSF14 & & & & & & & & & & & & & 1 & $.949^{* *}$ \\
\hline $\begin{array}{c}\text { Patients' } \\
\text { satisfacti } \\
\text { on }\end{array}$ & & & & & & & & & & & & & & 1 \\
\hline
\end{tabular}

**. Correlation is significant at the 0.01 level (2-tailed).

From the data illustrated in Table (13), it can be seen that there is a significant positive relationship between Patients' satisfaction about the comprehensive medical tour/visit to Egypt (in general) and to the hospital (in specific) and hospitality services and facilities elements; hospital reservation and registration procedures (HSF1) is .981, hospital internet services (HSF2) is .953, travel and transportation services (HSF3) is .966, hospital welcoming and accommodation services (HSF4) is .977, quality of patient room (HSF5) is .962, grooming and performance of housekeeping staff (HSF6) is .972, medical services follow up and facilities (HSF7) is .962, food quality and menu (HSF8) is .982, food service and cafeteria facility (HSF9) is .959, performance of food service staff (HSF10) is .977, hospital spa, wellness and therapy programs (HSF11) is .774, dry clean and laundry facilities and services (HSF13) is .883 and companions' (non-patient guests) accommodation (HSF14) is .949. Where that sig. $=0.000<0.01$, there is a significant positive relationship between hospitality services and facilities elements and patients' satisfaction about the comprehensive medical tour/visit to Egypt (in general) and to the hospital (in specific).

Table 14 : Multiple Linear Regressions model for dependent and independent variables

\begin{tabular}{|c|c|c|c|}
\hline Variables & Model & $\mathrm{B}$ & Std. Error \\
\hline Dependent Variable & Patients' satisfaction & $* 0.194$ & 0.178 \\
\hline \multirow{13}{*}{ Independent Variables } & HSF1 & 0.094 & 0.224 \\
\hline & HSF2 & 0.332 & 0.092 \\
\hline & HSF3 & 0.064 & 0.188 \\
\hline & HSF4 & -0.368 & 0.291 \\
\hline & HSF5 & 0.649 & 0.235 \\
\hline & HSF6 & 0.882 & 0.283 \\
\hline & HSF7 & -0.432 & 0.237 \\
\hline & HSF8 & -0.297 & 0.248 \\
\hline & HSF9 & -0.195 & 0.205 \\
\hline & HSF10 & 0.112 & 0.245 \\
\hline & HSF11 & -0.042 & 0.211 \\
\hline & HSF13 & 0.101 & 0.113 \\
\hline & HSF14 & 0.058 & 0.167 \\
\hline \multirow{5}{*}{ Statistical Values } & F Value & \multicolumn{2}{|c|}{187.38} \\
\hline & Sig. & \multicolumn{2}{|c|}{0.000} \\
\hline & $\mathrm{R}$ & \multicolumn{2}{|c|}{0.993} \\
\hline & $\mathrm{R}^{2}$ & \multicolumn{2}{|c|}{0.987} \\
\hline & Std. Error of the Estimate & \multicolumn{2}{|c|}{0.159} \\
\hline
\end{tabular}

The multiple linear regressions between independent variables and dependent variable were as follows:

$\mathrm{Y}=0.194+0.094 \times 1+0.332 \times 2+0.064 \times 3-0.368 \times 4+0.649 \times 5+0.882 \times 6-0.432 \times 7-$ $0.297 \times 8-0.195 \times 9+0.112 \times 10-0.042 \times 11+0.101 \times 13+0.058 \times 14$.

Where the $\mathrm{Y}=$ Patients' satisfaction, $\mathrm{x} 1=\mathrm{HSF} 1, \mathrm{x} 2=\mathrm{HSF} 2, \mathrm{x} 3=\mathrm{HSF} 3, \mathrm{x} 4=\mathrm{HSF} 4$, $\mathrm{x} 5$ = HSF5, x6 = HSF6, x7 = HSF7, x8 = HSF8, x9 = HSF9, x10 = HSF10, $\mathrm{x} 11=$ HSF11, x13 = HSF13, x14 = HSF14.

The results of the multiple linear regressions model showed a strong correlation between independent variables (Hospitality Services and Facilities elements) and 
dependent variable (Patients' satisfaction), where the $\mathrm{R}$ value is (0.993), which indicates the strength of the independent variables effect on the dependent variable.

There $\mathrm{R}^{2}$ value for independent variables is $(0.987)$, indicating that these variables explain 99\% changes in Patients' satisfaction.

The $\mathrm{F}$ value in the regressions model is $(187.38)$, and (sig. $=0.000<0.01$ ), indicating that significant effect between independent variables (Hospitality Services and Facilities elements) and dependent variable (Patients' satisfaction).

Second: Interview Analysis

The research has tackled an interview with managers working in seven JCI certified hospitals whose positions are related to the medical tourists' hospitality service such as marketing, public relation and international medical relation managers. According to interviewees' responses, the following findings have been reached.

Percentage of the total number of medical tourists visited each hospital in 2017

The average number of medical tourists who visited the JCI certified hospitals represents approximately $13 \%$ out of the total number of patients during 2017 . Table (15) clarifies in details this average percentage

Table 15: Percentage of medical tourists in 2017

\begin{tabular}{|l|c|}
\hline Name of hospital & \% of medical tourists out of total number of patients \\
\hline Saudi German Hospital & $14 \%$ \\
\hline Al O'youn Al Dwali & $9 \%$ \\
\hline As Salam International Hospital & $14 \%$ \\
\hline Wadi El Nile Hospital & $15 \%$ \\
\hline Dar El Fouad & $14 \%$ \\
\hline Maghrabi Hospital & $12 \%$ \\
\hline El Arabi Hospital & $13 \%$ \\
\hline Total & $91 \%$ \\
\hline Average & $13 \%$ \\
\hline
\end{tabular}

\section{Availability of a special unit in medical tour management}

Five hospitals only, representing approximately $70 \%$ of the visited hospitals, have a unit/division specialized in Medical Tourists' services. One of them names this unit "The international public relation department". The main functions of these units are stated as follows:

- Signing contracts with international medical insurance companies that deal with different patients' nationalities

- Assist in preparing the marketing campaign and launching it with the marketing department to attract a larger number of medical tourists

- Pre-arrangement of the medical tourist visits before his/her arrival and inform the patient with all details as well as communicating with different related departments in the hospital to provide the hospitality and medical services needed during the medical tourist visit

- Arranging the medical tourist visit from arrival to departure including hospital reservation, choice of doctor or assign a specialized surgeon and prepare treatment agenda, operation day, accommodation of the companions, flight ticket, meeting and assisting at the airport, transportation, follow up medical tourist needs and requirement during accommodation, solving problems, departure at the airport and finally follow up after treatment

- Evaluating patient's satisfaction during stay at the hospital at the end of the treatment and before departure 
- Setting up data base about all medical tourists who visited the hospital including the personal data, type of disease, disease history, operation done and received treatment, medications and patients' needs and requirements

- Preparing reports regarding problems faced by each medical tourist and solutions done

- Preparing reports about the benefits resulted from medical tourists' visit Whereas, the other two hospitals, sharing 30\% of the visited hospitals, manage medical tourism services by other departments like public relation, marketing and patients' service departments. It has been noticed that these two hospitals are specialized in optical treatment which are Al O'youn Al Dwali and Al Maghraby International hospital

Marketing campaigns employed in hospitals to attract a larger number of medical tourists

There are fragmented answers regarding the employed marketing campaign for reaching medical tourists, since each hospital is dealing with a specific marketing tool in terms of the following:

- Some hospitals are dealing with well-known medical insurances companies e.g. Saudi German and Wadi El Nil hospitals signed agreements with famous medical insurance companies in the Gulf area, which is the targeted market for the medical tourism in Egypt.

- El Arabi hospital management prepares a yearly visit to some African countries such as Nigeria, Chad, South Africa, Kenia and Sudan as they visit the famous medical centers and hospitals in these countries and sign protocols with responsible managers to transfer some medical cases that take long treatment like Virus $\mathrm{C}$ diseases as well as those cases that need serious operations like heart and brain operations which are difficult to be done in their countries.

- Wadi El Nil hospital has signed a protocol with the World Health Organization (WHO) to contact 24 medical centers and international medical insurance companies like Gopa, Signa and Alico in different nations such as Asia, Europe and Africa and also to sign agreement with medical insurance companies of those tourists who visit Sharm El Sheikh and Hurghada to transfer such tourists to the hospital in case of accidents or sudden health problems.

- Other hospitals like Dar El Fouad, El Salam, Wadi El Nil and EL Oyoun El Dawli hold conferences on a yearly basis and invite owners of some medical insurance companies and advertise for their medical services and their ability to receive medical tourists

- There are some hospitals that depend on the names and reputation of their doctors and surgeons which are enough to attract a large number of medical tourists

- EL Oyoun El Dwali and Saudi German hospitals invite professional international doctors and surgeons in specific period of the year, especially in summer, to cure some chronic diseases and do some big operations. Hospitals advertise for these international doctors' visits six months before their visit so as to attract a good number of medical tourists during the visit.

- Another marketing tool is used by Saudi German hospital through arranging for a complementary one week trip of managers and owners of well-known medical insurance companies, hospitals and medical centers' in Gulf area and Africa. They visit Saudi German hospital to inspect rooms, intensive care units, surgery areas, and cafeteria, kitchen, waiting lounge and reception places. They also make interviews with doctors and hospital staff to guarantee the quality of medical, 
nursing and hospitality services offered in the hospital. Surely, these visits assist in attracting a larger number of medical tourists

On the other hand, there are similar answers regarding the utilized marketing tools such as the following:

- Advertising through social media and their website on the internet as well advertising through medical pages on the internet.

- Advertising in different hospitals and medical centers' newsletter

- Advertising in the T.V and Radio of the countries of the targeted medical tourists' market.

- Reducing prices of the operations and medical visits, which are almost near to those offered to Egyptians

- Adding a call center for medical tourism and prepare a digital marketing plan that are submitted and shown on the web-site

- Creating public relations with consulates and embassies of those countries that represent an active targeted market for the medical tourism

\section{Nationalities of the medical tourists who frequently visit the hospital}

The Gulf area is the first marketing zone that delivers medical tourism to Egypt since $80 \%$ of respondents stated that Gulf area, with focusing on Saudi Arabian, Kuwaiti and Yemini, are the most important nationalities for medical tourism in Egypt. Then, Africa area comes as a second rank as one hospital manager, which is El Arabi International Hospital, confirmed that Africans are the basic source of medical tourism to El Arabi hospital. The European area comes as a third rank since one hospital manager, Wadi El Nil hospital, stated that some European tourists that visit Sharm and Hurghada, such as German, Russian, Ukrainian, Australian and Italian tourists are transferred to the hospital in case of emergencies or sudden health crises during their tourist visit.

\section{Importance of JCI certificate for attracting medical tourists to the hospital}

$50 \%$ of interviewees mentioned that JCI certificate is a credit and considered an actual marketing instrument for attracting medical tourism to any hospital. This is due to the fact that many medical insurance companies look for the JCI certificate as a condition before signing the agreement with the hospital to guarantee the proficiency of the medical services offered to patients. On the other hand, other $50 \%$ of respondents stated that JCI certificate is not important as it is just a documentation of paper and neither patients nor medical insurance companies aware about its significance.

\section{Treatment types mostly required by medical tourists}

Respondents working in Ocular Treatment hospitals (El Oyoun El Dwali and El Maghraby) confirmed that Rhegmatogenous operations are the first and most important treatment frequently required by medical tourists in optical hospitals in Egypt. Then, Corneal Transplantation comes as the second rank of importance. Cataract Surgery comes as the third important treatment type needed by medical tourists. They also added that medical tourists always require big operations that take at least 10 days for convalescing after operation. Medical tourists mostly are not requiring simple operations like Lasix as this is too simple and does not deserve the cost of travelling to another country for treatment.

Regarding the responses of the other 5 visited hospitals (Dar El Fouad, El Salam International Hospital, Wadi El Nil, El Arabi and Saudi), the following has been clarified: 
- Three interviewees, representing $60 \%$ of visited managers, confirmed that kidney transplantation comes as a first category of operations required by medical tourists. Then, Open heart operations comes as a second category, and brain surgery regarded as third important rank

- Two managers only, representing $40 \%$ of respondents, stated that the required treatment depends on the nationality of the patient. For example, Libyan are famous for kidney transplantation, Arab Gulf nationalities are known for big operations as well as skin and optical diseases treatment, whereas, Jordanians require female diseases.

- All of interviewees mentioned that very few cases for cosmetics and plastic surgery are required by medical tourists

Training programs to the Hospitality service staff

$100 \%$ of visited hospitals implement training programs to the hospitality staff such as food and beverage, housekeeping, reception and kitchen staff. All of them execute the training on a yearly basis to qualify hospitality staff dealing with the medical tourists. These programs are embodied in the following:

- English Language skills development

- Dealing with different nationalities

- Hospitality Service Skills

- Hygiene and Sanitation

- Nutrition

- Food Safety

- How to maintain high standards of cleanliness and sanitation of patient room

- Advanced technical specialized courses to receptionists, food service staff and housekeeping

Some of them signed agreement with specialized consulting companies e.g. Wadi El Nile and Dar El Fouad Hospitals signed a protocol with international medical tourism consulting company like "Next Care" to provide the training programs through preparation of training needs analysis first and manage the process of staff training including the hospitality service staff

Implementation of medical tourists' satisfaction program on a periodical basis Four hospitals, representing $57 \%$ of visited hospitals implement medical tourists' customer satisfaction program on a periodical basis. According to respondents of interviewees, they are handling very few numbers of complaints; however, the following are the mostly repeated complaints:

- Late response to the urgent call of the guest during his stay at the room

- Weak English language skills of nursing and service staff with difficulty in communicating with non-Arab medical tourists

Availability of a building within the hospital for the lodging of patients' companions No hospital possesses a building within the hospital for the lodging of patients' companions. However, 4 hospitals are arranging for companions' accommodations in terms of the following:

- Dar El Fouad hospital singed a contract with Novotel $6^{\text {th }}$ October hotel to provide special prices to patients' companions.

- Saudi German, Wadi El Nile and Asalam International hospitals are facilitating the process of reserving hotel guest rooms for accommodating patients' companions but it is not included in the total price of medical tourist visit. 
- All respondents stated that single companion is accommodated in the patient room as the hospital provide extra bed or accommodate the patient together with the companion in a large room or medical suite within the hospital with good facilities.

\section{Facilities offered to attract medical tourists to hospitals}

Depending on interviewees' responses, the distinguished elements and unique facilities offered by the visited hospitals that attract medical tourists and reflect a positive image about medical tourism in Egypt are exemplified in the following:

- VIP lounge for the medical tourist arrival and registration in the hospital

- Agreement with travel services companies to cover the services of medical tourist such as airline reservation, transfer from the airport to the hospital and vice versa, accommodation of the patient companions, tour management

- Plan a tour and cure plan to medical insurance companies' representatives and the expenses are covered by the hospital

- Availability of suites for single companions

- Having pioneer doctors and surgeons that attract the medical tourists to the hospital

- Visit of international well-known medical experts for specific period that attract medical tourists during this time and processing some medical surgeries

- Making workshops in the chamber of trade for increasing the awareness of the medical tourism and the concept of VIP management

\section{Medical tourists' sightseeing}

All interviewees mentioned that they are not arranging for medical tourists' sightseeing as it is not included in the medical tourist visit. However, they stated that if the patient required sightseeing program, the hospital can assist in arranging for such program in collaboration with contracted travel agents.

\section{Difficulties facing medical tourists in the hospital}

Respondents mentioned that most the important difficulties and repeated problems facing medical tourists are illustrated in the following:

- The routine procedures and problems the medical patient faces during his transportation from the airport to the hospital and vice versa.

- Lack of monitoring and supervision of the governmental authorities for controlling the routine faced by tourists or even minimize its negative image. Furthermore, there is no entity in the government that receives and handles medical tourist complaints. For example, if there is a critical medical mistake done by the Egyptian doctor or surgeon that caused serious health problem to the tourist, there is no entity that adopts, follow up and solve the problem. Accordingly, the patient refers back to his/her embassy, the fact that consequently results in a bad reputation about medical tourism in Egypt.

- Lack of language skills for nursing and hospitality staff that deal with Non-Arab medical tourists

- Late response to the medical tourist calls which sometimes result in healthy problems to the patient

- Unpunctuality of surgeons which certainly leads to negative image about Egyptian doctors 


\section{Conclusion}

It has been concluded that JCI certified hospitals are performing unique professional activities to attract medical tourists to their establishment and increase their numbers, as well as to provide a high standards of hospitality services to medical tourists. These activities are regarded as a marketing and hospitality services guide presented to those hospitals that plan to receive and serve medical tourists in their establishments. These activities are summarized in the following:

- Establishing a unit or division in the hospital specialized in arranging medical tourist visit starting from tourist arrival to departure

- Signing a contract with international medical insurance companies for receiving their customers as medical tourists and providing medical and hospitality services to them

- Managing a program for medical tourism satisfaction by the end of their visit

- Holding a conference or medical event on a yearly basis through inviting hospital owners, well known physicians and international medical insurance companies' representatives

- Arranging for one-week free visit of managers and owners of international medical centers and hospitals in the Gulf Area and African countries

- Concentrate the marketing campaign on the best markets of medical inbound tourism to Egypt such as the Gulf area and African Countries

- Concentrate the marketing campaign on the required treatment types that mostly required by medical tourists such as kidney transplantation, general surgery and open heart operation, this is plus ocular treatments like Rhegmatogenous operations and Corneal Transplantation in optical hospitals

- Signing a contract with one of the training centers specialized in hospitality services skills development, so as to upgrade the hospitality skills of the service staff in the hospital

- Preparing database of most frequently visited medical tourists

On the contrary, there are some weak points that should be avoided by those hospitals that intend to receive medical tourists and developed in the future. They are exemplified in the following:

- There is limited arrangement of the accommodation of the medical tourists' companions

- There are no entertainment activities offered to medical tourists during their stay

- There are no sightseeing programs arranged for medical tourists during their medical visit

\section{Recommendations and Implications}

First: Recommendations for governmental authorities

- Make up rules and regulations for the management of medical tourism in Egypt, issued and published by one of the concerned authorities related to medical tourism activities such as Ministry of Health or Ministry of Tourism. These rules and regulations must involve the ethics of dealing with medical tourists and supported by a decree for dictating penalties and punishment against any medical center that un-follow or break those rules and regulations.

- Setting up a guide of Medical Tourism Hospitality standards, to be made and issued by the Ministry of Tourism. This list includes a list of hospitality standards at hospitals and demonstrates the quality of hospitality services offered to medical tourists. It should be distributed among all hospitals 
- Establishing a committee in the government that includes members representing different associations related to medical tourism so as to discuss the main problems of medical tourism in Egypt and propose the solutions of such problems. This committee should also prepare strategies for improving medical tourism services in Egypt and increase the number of medical tourists directed to Egypt.

- Set up an entity, in partnership with the ministry of tourism and the ministry of Health, to receive all cases and complaints of medical tourists, follow up with them and advocate their legal rights in case of any health or operations' mistakes done by Egyptian physicians or surgeons.

- Establishing a unit in the Egyptian Tourism Promotion Boards for supporting the promoting and marketing activities favor medical tourism in Egypt, in cooperation with Egyptian hospitals that receive regularly medical tourists all over the year.

- Adopting a system, by the Ministry of Health, for communication among JCI hospitals to coordinate with each other medical tourists visit and assign specialization for each hospital. Community should be set with the involvement and sharing of JCI certified Hospitals

- Preparing training programs, by the Ministry of Tourism, for skills development of hospitality staff that work in hospitals, with special focus on those that deal with medical tourists.

Second: Recommendations for hospitals

- Sign protocols with travel agents to support the medical tourist visit with sightseeing and tours to the historical and cultural places as well as tourist attractions in Egypt

- Make contracts with hotels to provide special offer prices to medical tourists' companions to facilitate their accommodation during the medical tourist visit

- Assign a budget, especially in the famous and well known hospitals in Egypt, to build a housing unit for accommodating medical tourists' companions. This budget should also include the building and establishment of health club and entertainment centers within the hospitals to be credit for receiving and serving medical tourists

- Prepare specialized programs for improving the language skills of nursing and hospitality service staff that deal with medical tourists

Third: Recommendations for future researches

It is recommended to prepare the following researches that more or less depend on this research results and recommendations.

- Developing a marketing campaign for attracting a larger number of medical tourists in Egyptian hospitals

- Setting up hospitality services standards offered to medical tourists in the local Egyptian hospitals.

- Improving the entertainment services offered to medical tourists in Egyptian hospitals

- Setting up fitness programs during the convalescence of medical tourists in the Egyptian hospitals

\section{References}

Abu-ElEnain, E. and Yahia, S. (2016). Developing medical tourism in Egypt, benchmarking on Dubai, UAE. International Journal of Science Research and Technology, 2(3): 15-22.

Adams, A. (2008). Medicine by design. Minneapolis: University of Minnesota Press. 
Al-Hinai, S., Al-Busaidi, A., \& Al-Busaidi, I. (2011). Medical tourism abroad. A new challenge to Oman's health system e Al Dakhilya region experience. Sultan Qabus University Medical Journal, 11, 477-484.

Alsharif, M., Labonté, R., \& Zuxun, L. (2010). Patients beyond borders: a study of medical tourists in four countries. Global Social Policy, 10, 315-335.

Anon. (2010). MTA releases first patient surveys on medical tourism. Medical Tourism Magazine, 10, 34-36.

Ayoub, M. (2017). Medical tourism in Egypt: opportunities and challenges. Unpublished Master Thesis. School of Global Affairs and Public Policy. The American University in Cairo.

Becker. F., Sweeney, B. \& Parsons, K. (2008). Ambulatory facility design and patients' perceptions of healthcare quality. Health environments research and design journal, 1(4), 35-54.

Beerli, A. \& Martín, J. D. (2004). Tourists' characteristics and the perceived image of tourist destinations: a quantitative analysisda case study of Lanzarote, Spain. Tourism Management, 25(5), 623-636.

Bennett, M., King, B. \& Milner, L. (2004). The health resort sector in Australia: A positioning study. Journal of Vacation Marketing, 10 (2): 122-137.

Bookman, M., \& Bookman, K. (2007). Medical tourism in developing countries. Basingstoke: Palgrave Macmillan.

Cohen, E. (2008). Medical tourism in Thailand. In E. Cohen (Ed.), Explorations in Thai tourism. Bingley: Emerald, 225-255.

Connell, J. (2006). Medical tourism: Sea, sun, sand and surgery., Tourism Management, 27 (6): 1093-1100.

Connell, J. (2013). Contemporary medical tourism: Conceptualization, culture and commodification. Tourism Management, 34, 1-13.

Delgoshaee, B., Jabbari, A., Farzin, M., Sherebafchizade, N., \& Tabibi, S. (2012). Current status of medical tourism: case study of Iran. Quarterly of Payesh, 2(1), 171-179.

Dunn, P. (2007). Medical tourism takes flight. Hospital Health Network, 81, 40-44.

Edelheit, J. (2008). Defining medical tourism or not? Medical Tourism Magazine, 5, 9-10.

Edwards, J. \& Hartwell, H. (2006). Hospital food service: a comparative analysis of systems and introducing the 'Steamplicity' concept, J Hum Nutr Diet, 19(6): 421430.

Fottler, M.D., Dickson, D., Ford, R.C., Bradley, K. and Johnson, L. (2006). Comparing hospital staff and patient perceptions of customer service: a pilot study utilizing survey and focus group data. Health Services Management Research, Vol (19), 52-66.

Gill, H., \& Singh, N. (2011). Exploring the factors that affect the choice of destination for medical tourism. Journal of Service Science and Management, 4(03), 315.

Glinos, I., Doering, N., \& Maarse, H. (2012). Travelling home for treatment and EU patients' rights to care abroad: results of a survey among German students at Maastricht University. Health Policy, 105, 38-45.

Goldman, D. \& Romley, J. (2008). Hospitals as hotels: the role of patient amenities in hospital demand. Cambridge, MA: National Bureau of Economic Research.

Guzman, J. (2014). Hospitality in Hospitals. Feinstein Graduate School. Johnson and Wales University, pp. 10-17. 
Helmy, E. (2011). Benchmarking The Egyptian Medical Tourism Sector Against International Best EST Practices: An N Exploratory Study. Tourismos: An International Multidisciplinary Journal of Tourism. 6(2). 293-311.

Henderson, J. (2004). Healthcare Tourism in Southeast Asia., Tourism Review International, 7 (3-4): 111-21.

Heung, V., Kucukusta, D., \& Song, H. (2010). A conceptual model of medical tourism: implications for future research. Journal of Travel and Tourism Marketing, 27, 236-251.

Heung, V., Kucukusta, D., \& Song, H. (2011). Medical tourism development in Hong Kong: an assessment of the barriers. Tourism Management, 32(5), 995-1005.

Hollis, B. \& Verma, R. (2012). The intersection of hospitality and healthcare: Exploring common areas of service quality, human resources and marketing. Cornell hospitality proceedings.

Ile, F. (2016). Medical tourism market - trends in the context of globalization, in Emerging Markets Economics and Business; Contributions of Young Researchers; Proceedings of the 7th Conference of Doctoral Students in Economic Sciences, University of Oradea, Faculty of Economic Sciences, No. 4 December 2016.

Jagyasi, P. (2008). Defining medical tourism. Another approach. Medical Tourism Magazine, 6, 9-11.

Joint Commission International (JCI). (2017). Facts about The Joint Commission. Available

at: https://www.jointcommission.org/facts_about_the_joint_commission/. (Accessed 21 June 2018)

Kangas, B. (2010). Traveling for medical care in a global world. Medical Anthropology, 29, 344-362.

Kazemi, M. (2006). Management of Tourism, Samt, Tehran.

Kazemi, Z. (2008). Study of the effective factors for attracting medical tourism in Iran. Unpublished Master's Thesis. Iran: Lulea University of Technology.

Kumar, J. \& Hussian, K. (2016). Factors Affecting Medical Tourism Destination Selection: A Malaysian Perspective. International Interdisciplinary BusinessEconomics Advancement Journal, 1(1): 1-10.

Larisa, F. \& Tigu, G. (2017). Medical tourism market trends - an exploratory research. Proceedings of the International Conference on Business Excellence, 11 (1), 1111-1121, [online] available on: https://doi.org/10.1515/picbe-2017-0114. (Accessed 5 May 2018)

Lashley, C. and Morrison, A. (2000), In Search of Hospitality: Theoretical Perspectives and Debates, Butterworth-Heinemann, Oxford.

Laurren, K. (2013). Practitioner Application - The Application of Hospitality Elements in Hospitals Journal of Healthcare Management. 58 (1): 62-63.

Mentziou, I., Delezos, C., Nestoridou, A. \& Boskou, G. (2014). Evaluation of food services by the patients in hospitals of Athens in Greece. Health Science Journal, 8(3), 383-392.

Naithani, S., Thoma, J., Ehelan, K., Morgan, M. \& Gulliford, M. (2009). Experiences of food access in hospital. A new questionnaire measure. Clin Nutr, 28(6):625630.

Navid F., Ahmad P. \& Yuserrie Z. (2010). Service Quality and Patients' Satisfaction in Medical Tourism. World Applied Sciences Journal 10 (Special Issue of Tourism and Hospitality): 3-24. 
Oh, H. and Pizam, A. (2008), Handbook of Hospitality Marketing Management, Boston, MA: Butterworth-Heinemann.

Ornstein, C. \& Glionna, J. (2008). After livers, cash to UCLA. Los Angeles Times, May 31.

Padma, T. (2006). Unchecked by guidelines, India stem cell scientists rush ahead., Nature Medicine, 12 (1): 4.

Ramirez de Arellano, A. (2011). Medical tourism in the Caribbean. Signs, 36, 289297.

Reisman, D. (2010). Health tourism. Social welfare through international trade. Cheltenham: Edward Elgar.

Rory, J., Valorie, C. Jeremy, S. \& Paul, K. (2010). What is known about the effects of medical tourism in destination and departure countries? A scoping review. International Journal for Equity in Health 9:24.

Rutes, W., Penner, R. \& Adams, L. (2001). Hotel design, planning and development. New York, NY: W. W. Norton.

Sadrmomtaz, N., \& Agharahimi, Z. (2010). Medical tourism in Iran; guidelines for development. Management of Health Information, 7, 516-524.

Smith, M., \& Puczko, L. (2009). Health and wellness tourism. Oxford: Elsevier.

Smith, R., Martínez Álvarez, M. \& Chanda, R. (2011). Medical tourism: a review of the literature and analysis of a role for bi-lateral trade. Health Policy, 103(2-3), 276-282.

Valorie, C., Leigh, T., Jeremy, S., Rory, J. \& Paul, K. (2011). Promoting medical tourism to India: Messages, images, and the marketing of international patient travel. Social Science and Medicine. 72:726-732.

Veerasoontorn, R., Beise-Zee, \& Sivayathorn, A. (2011). Service quality as a key driver of medical tourism: the case of Bumrungrad International Hospital in Thailand. International Journal of Leisure and Tourism Marketing, 2, 140-158.

Vitthal, P., Subhash A., Sharma, B. \& Ramachandran, M. (2015). Emerging Trends and Future Prospects of Medical Tourism in India. Journal of Pharmaceutical Sciences and Research, 7(5):248-251.

Wu, Z., Robson, S., Brooke, H. \& Laureen, T. (2013). The application of hospitality elements in hospitals. Journal of healthcare management, 58(1), 47-63.

$\mathrm{Yu}$, J., \& Ko, T. (2012). A cross-cultural study of the perceptions of medical tourism among Chinese, Japanese and Korean tourists in Korea. Tourism Management, $33,80-88$. 